\title{
THE EOMYIDAE IN ASIA: BIOGEOGRAPHY, DIVERSITY AND DISPERSALS
}

\author{
YURI KIMURA ${ }^{1,2, *}$, ISAAC CASANOVAS-VILAR², OLIVIER MARIDET ${ }^{3,4}$, DANIELA C. KALTHOFF $^{5}$, \\ THOMAS MÖRS ${ }^{6}$, YUKIMITSU TOMIDA $^{1}$
}

\author{
1 Department of Geology and Paleontology, National Museum of Nature and Science, 4-1-1 Amakubo, Tsukuba, Ibaraki, 305-0005, Japan; \\ e-mail: ykimura.research@gmail.com. \\ ${ }^{2}$ Institut Català de Paleontologia Miquel Crusafont, ICTA-ICP. Edifici Z. Carrer de les Columnes, s/n., Campus de la Universitat Autònoma \\ de Barcelona, E-08193 Cerdanyola del Vallès, Barcelona, Spain. \\ 3 JURASSICA Museum, Route de Fontenais 21, CH-2900 Porrentruy, Switzerland. \\ ${ }^{4}$ Département des Géosciences, Université de Fribourg, Chemin du Musée 6, CH-1700 Fribourg, Switzerland. \\ ${ }^{5}$ Department of Zoology, Swedish Museum of Natural History, P.O. Box 50007, SE-104 05 Stockholm, Sweden. \\ ${ }^{6}$ Department of Palaeobiology, Swedish Museum of Natural History, P.O. Box 50007, SE-104 05 Stockholm, Sweden. \\ *corresponding author
}

Kimura, Y., Casanovas-Vilar, I., Maridet, O., Kalthoff, D. C., Mörs, T., Tomida, Y. (2019): The Eomyidae in Asia: Biogeography, diversity and dispersals. - Fossil Imprint, 76(1): 181-200, Praha. ISSN 2533-4050 (print), ISSN 2533-4069 (on-line).

\begin{abstract}
In Asia, the first find of an eomyid rodent was reported almost one century after the first studies of the family Eomyidae in North America and Europe. Since then, eomyid rodents have been increasingly found in Asia particularly over the past two decades. Here, we review the Asian record of this family at the genus level. Currently, 22 species within 14 genera were reported from Asia, including seven endemic genera and rare materials of apeomyine eomyids. Eomyids emphasize the palaeogeographic importance of Asia in considering intercontinental dispersal events of small mammals. With newly compiled data for Asian eomyids, we also compare genus-level diversity trends through time among North America, Europe, and Asia. Despite data standardizations limited with respect to potential biases in the fossil record, we found that the Asian eomyid diversity closely follows ecological shifts induced by climate changes. In general, Asian eomyid genera disappeared earlier than their European counterparts. We suggest that this pattern is not dictated by differences in the quality of the fossil record and is related to the expansion of drier habitats over large areas of Asia.
\end{abstract}

Key words: Rodentia, Eomyidae, palaeobiogeography, intercontinental dispersal, Valley of Lakes, Nei Mongol, Inner Mongolia, Junggar Basin, endemism

Received: April 2, 2019| Accepted: December 13, 2019 | Issued: November 9, 2020

\section{Introduction}

The Eomyidae is an extinct family of small to mediumsized rodents, which are presumed to be phylogenetically close to geomyoid rodents (gophers, kangaroo rats) based on shared cranial characters (Wahlert 1978, Flynn 2008). Many of them are considered to have occupied similar niches to extant dormice, preferably inhabiting warm-temperate forest environments (Engesser 1999). However, eomyids probably occupied more ecological niches than dormice, as suggested by their more diverse dental morphology from bunodont to lophodont with increasing crown heights (Engesser 1999). Although most species of eomyid rodents are known based on isolated teeth only and a few mandible and skull fragments, two beautifully preserved specimens unearthed from the late Oligocene locality Enspel (Germany) evidence the great ecological disparity of this family. One of them, Eomys quercyi, preserves the outline of a patagium supported by a cartilage originating from the elbow, much like that of scaly-tailed flying squirrels (Anomaluridae), revealing that this rodent was a glider (Storch et al. 1996). The other specimen preserves soft body parts of Eomyodon volkeri, showing that the species is a generalised terrestrial form (Engler and Martin 2015).

In Asia, the first reported eomyid fossil is a right jaw belonging to a new species of the American genus Leptodontomys from the late Miocene of North China (Zheng and Li 1982). Almost one century had passed since the first studies of the Eomyidae in North America and Europe (Cope 1884, Schlosser 1884). In the 1990s, a handful of eomyid fossils had been found in North China and Kazakhstan, including Symplokeomys zaysanicus, which marks the oldest occurrence (late Eocene) of the family in Asia (Emry et al. 1997), and Asian species of Eomys, Pseudotheridomys, 
and Eomyodon (Wang and Emry 1991, Lopatin 2000, Wang 2002). Meanwhile, in Japan, a small eomyid fossil was discovered in the early Miocene deposits of Gifu and identified as Pseudotheridomys sp. (Tomida and Setoguchi 1994). In the 2000s, Wu et al. (2006) erected the Asian genus Asianeomys and transferred the following species to it: the Asian species of Pseudotheridomys (P. asiaticus from Inner Mongolia, China, P. yanshini from Kazakhstan) and Eomyodon dangheensis from Gansu Province, China. To date, six species of Asianeomys have been recorded from North China (Wu et al. 2006, Maridet et al. 2011, Gomes Rodrigues et al. 2014, Qiu and Li 2016), Mongolia (Maridet et al. 2015), and Kazakhstan (Lopatin 2000), with recent finds of the richest material in Inner Mongolia, China (Qiu and Li 2016) and Central Mongolia (Maridet et al. 2015). Most recently, the Japanese material ascribed to Pseudotheridomys sp. was transferred to a new genus, Japaneomys, closely related but basal to Asianeomys (Kimura et al. 2019), and Omboomys was erected for a small-sized bunodont eomyid lacking mesoloph(id) from Mongolia (Maridet et al. 2015). Likewise, apeomyine eomyids were recently discovered in Asia although the reported materials include only one tooth of Apeomys from Sihong, Jiangsu Province, central East China (Qiu 2017) and a single tooth of Megapeomys from Kani, Gifu, central Japan (Tomida 2011). Discoveries of eomyid rodents have been centered in mid-high latitudes, which have been more intenstively studied, but they also occcur in southern regions. Currently, up to three endemic genera
(Heteroeomys, Plesieomys, Yuneomys) were discovered from the hominoid-bearing sites in Lufeng, Yunnan Province, southwestern China (Qiu 2006, 2017). As summarised above, the fossil records in continental Asia and a locality in Japan have remarkably increased our understanding of the evolution and biogeography of the Eomyidae for the last two decades. Yet, no updated account has been published since the last review of Chinese eomyids by Qiu (1994). Here, we review the Asian record of eomyids at the genus level. For each genus, we provide a list of the included Asian species and main sites as well as a brief description of their dental characteristics including further considerations and remarks. Furthermore, we compiled taxonomic data for each species from a given locality based on original references and compared genus-level diversity trends of the family Eomyidae in North America, Europe, and Asia.

\section{Material and methods}

The first and last occurrences of all eomyid rodents were compiled for North America, Europe, and Asia in order to explore diversity dynamics of the family in each of these continents (Tab. 1). For North American taxa, data were taken from the Paleobiology Database (PBDB, downloaded on July 3, 2017 from https://paleobiodb.org/ classic/displayDownloadGenerator) and updated to include the recent new findings reported by Flynn (2008), Korth (2008), and Korth and Samuels (2015). For European

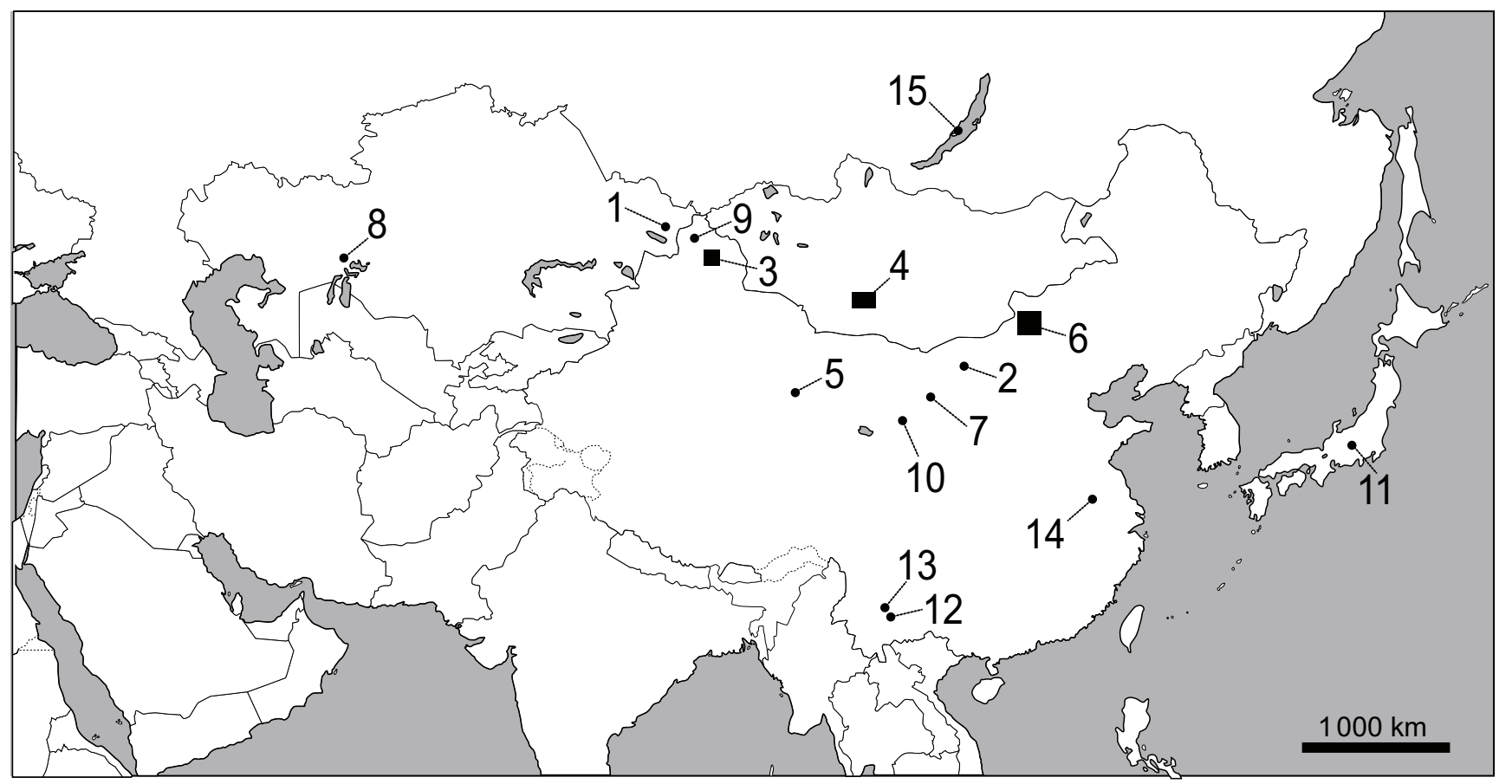

Text-fig. 1. Distribution of fossil localities where eomyid rodents were discovered. 1: Sunduk, Kazakhstan, 2: Saint Jacques, Inner Mongolia, China: 3: Tieersihabahe in the Junggar Basin, Xinjiang, China, 4: 11 localities (Taatsiin Gol (right), Hasanda Gol, Tatal Gol, Taatsiin, Del, Huch Teeg, Unkheltseg, Luuny Yas, Hotuliin Teeg, Ulaan Tolgoi, Builstyn Khudag) in the Valley of Lakes, Mongolia, 5: Yandantu (Danghe area), Gansu, China, 6: 5 localities (Lower Aoerban, Gashunyinadege, Upper Aoerban, Balunhalagen, Bilutu) in Sonid Zuoqi, 3 localities (Amuwusu, Shala, Loc. 346) in Sonid Youqi, 2 localities (Ertemte2, Harr Obo2) in Huade, Huitenghe in Abag qi, Inner Mongolia, China, 7: Ulantatal, Inner Mongolia, China, 8: Altynshokysu, Aktyubinsk, Kazakhstan, 9: Burqin, Habahe in the Junggar Basin, Xinjiang, China, 10: Songshan, Gansu, China, 11: Dota, Gifu, Japan, 12: Shihuiba, Lufeng, Yunnan, China, 13: Leilao, Yuanmou, Yunnan, China, 14: Sihong, Jiangsu, China, 15: Tagay in Olkhon Island, Lake Baikal, Siberia, Russia. More detailed information is provided in Appendix. 
Table 1. First and last occurrences of eomyid rodents at the genus level in Asia, Europe, and North America, corresponding to Text-fig. 10 and Appendix.

\begin{tabular}{|c|c|c|c|c|c|}
\hline Genus & $\begin{array}{c}\text { First } \\
\text { occurrence } \\
\text { (Ma) }\end{array}$ & $\begin{array}{c}\text { Last } \\
\text { occurrence } \\
\text { (Ma) }\end{array}$ & Region & Reference for min age & Reference for max age \\
\hline Apeomys & 16.9 & 16.9 & Asia & Qiu (2017) & Qiu (2017) \\
\hline Asianeomys & 26.5 & 18.4 & Asia & Qiu et al. (2013); Qiu and Li (2016) & Wang (2002); Wang et al. (2008); PBDB \\
\hline Eomys & 25.4 & 25.4 & Asia & Wang and Emry (1991) & Wang and Emry (1991) \\
\hline Heteroeomys & 8.5 & 8.5 & Asia & Qiu (2006) & Qiu (2006) \\
\hline Japaneomys & 18.5 & 18.5 & Asia & Kimura et al. (2019) & Kimura et al. (2019) \\
\hline Keramidomys & 19.5 & 6.4 & Asia & Qiu et al. (2013); Qiu and Li (2016) & Qiu et al. (2013); Qiu and Li (2016) \\
\hline Leptodontomys & 19.5 & 6.2 & Asia & Qiu et al. (2013); Qiu and Li (2016) & Qiu et al. (2013); Qiu and Li (2016) \\
\hline Ligerimys & 19.5 & 18.4 & Asia & Qiu et al. (2013); Qiu and Li (2016) & Qiu et al. (2013); Qiu and Li (2016) \\
\hline Megapeomys & 18.5 & 18.5 & Asia & $\begin{array}{l}\text { Takeuchi (1992); Tomida (2011); Mörs et } \\
\text { al. (2016) }\end{array}$ & $\begin{array}{l}\text { Takeuchi (1992); Tomida (2011); Mörs et } \\
\text { al. (2016) }\end{array}$ \\
\hline Omboomys & 9.2 & 9.2 & Asia & Maridet et al. (2015) & Maridet et al. (2015) \\
\hline Pentabuneomys & 19.5 & 9.4 & Asia & Qiu et al. (2013); Qiu and Li (2016) & Qiu et al. (2013); Qiu and Li (2016) \\
\hline Symplokeomys & 35.6 & 35.6 & Asia & Emry et al. (1997); PBDB & Emry et al. (1997); PBDB \\
\hline Yuneomys & 8.5 & 8.5 & Asia & Qiu $(2006,2017)$ & Qiu $(2006,2017)$ \\
\hline Apeomys & 23.2 & 16.8 & Europe & Mörs and Flink (2018) & Maridet et al. (2013) \\
\hline Eomyodon & 24.3 & 22.4 & Europe & Maridet et al. (2013) & Maridet et al. (2013) \\
\hline $\begin{array}{l}\text { Eomyops } \\
\text { (Leptodontomys) }\end{array}$ & 16.8 & 4.2 & Europe & Maridet et al. (2013) & Maridet et al. (2013) \\
\hline Eomys & 33.2 & 23.1 & Europe & Maridet et al. (2010) & Maridet et al. (2013) \\
\hline Estramomys & 5.2 & 2.2 & Europe & Maridet et al. (2013) & Maridet et al. (2013) \\
\hline Keramidomys & 15.3 & 5.2 & Europe & Maridet et al. (2013) & Maridet et al. (2013) \\
\hline Ligerimys & 20.9 & 16.8 & Europe & Maridet et al. (2013) & Maridet et al. (2013) \\
\hline Megapeomys & 18.4 & 16.8 & Europe & Mörs and Flink (2018) & Maridet et al. (2013) \\
\hline Pentabuneomys & 18.4 & 15.3 & Europe & Maridet et al. (2013) & Maridet et al. (2013) \\
\hline Pseudotheridomys & 25.0 & 16.8 & Europe & Maridet et al. (2013) & Maridet et al. (2013) \\
\hline Ritteneria & 22.4 & 20.1 & Europe & Maridet et al. (2013) & Maridet et al. (2013) \\
\hline Adjidaumo & 38.8 & 33.6 & North America & PBDB & PBDB \\
\hline Arikareeomys & 22.6 & 22.6 & North America & PBDB & PBDB \\
\hline Aulolithomys & 38.8 & 35.6 & North America & PBDB & PBDB \\
\hline Centimanomys & 35.6 & 35.6 & North America & PBDB & PBDB \\
\hline Cristadjidaumo & 38.8 & 35.6 & North America & PBDB & PBDB \\
\hline Cupressimus & 35.6 & 35.6 & North America & PBDB & PBDB \\
\hline Kansasimys & 7.6 & 7.6 & North America & PBDB & PBDB \\
\hline Leptodontomys & 28.6 & 7.6 & North America & PBDB & Korth (2008) \\
\hline Litoyoderimys & 38.8 & 35.6 & North America & PBDB & PBDB \\
\hline Megapeomys & 18.2 & 18.2 & North America & PBDB & PBDB \\
\hline Metadjidaumo & 33.6 & 28.6 & North America & PBDB & PBDB \\
\hline Metanoiamys & 43.3 & 35.6 & North America & PBDB & PBDB \\
\hline Namatomys & 35.6 & 35.6 & North America & PBDB & PBDB \\
\hline Orelladjidaumo & 33.6 & 33.6 & North America & PBDB & PBDB \\
\hline Paradjidaumo & 38.8 & 32.1 & North America & PBDB & PBDB \\
\hline Paranamatomys & 35.6 & 35.6 & North America & PBDB & PBDB \\
\hline Protadjidaumo & 43.3 & 38.8 & North America & PBDB & PBDB \\
\hline Pseudotheridomys & 25.6 & 14.8 & North America & PBDB & PBDB \\
\hline Viejadjidaumo & 38.8 & 38.8 & North America & PBDB & PBDB \\
\hline Yoderimys & 35.6 & 35.6 & North America & PBDB & PBDB \\
\hline Zemiodontomys & 35.6 & 35.6 & North America & PBDB & PBDB \\
\hline Montanamus & 35.3 & 35.3 & North America & Flynn (2008) & Flynn (2008) \\
\hline Aguafriamys & 38.5 & 38.5 & North America & Flynn (2008) & Flynn (2008) \\
\hline Apeomyoides & 15.4 & 15.4 & North America & Flynn (2008) & Flynn (2008) \\
\hline Comanchoeomys & 7.1 & 7.1 & North America & Flynn (2008) & Flynn (2008) \\
\hline
\end{tabular}


taxa, we utilized the dataset of Maridet et al. (2010, 2013), supplemented by Mörs and Flink (2018). We follow Engesser (1979) in considering Leptodontomys and Eomyops to be distinct genera although the validity of Eomyops is currently debated (Qiu 1994, Ruiz-Sánchez et al. 2009, Prieto 2012). For the Asian taxa, we compiled a detailed dataset based on the original literature (see Appendix). Age for upper and lower boundaries of MP and MN zones are taken from the Geologic Time Scale 2012 (Hilgen et al. 2012, Vandenberghe et al. 2012).

The median of the estimated range was used for the age of each fossil specimen. We excluded any entry whose age estimates range over 6 million years or identification is indeterminate at the species level. The choice of 6 million years for the quality control of the data is rather arbitrary to include the single occurrence of Asian Apeomys although age estimates are less than 3 million years for most of the localities. All genera but Zetamys, for which the age uncertainly of the only known locality is over 10 million years (Martin 1974), met the above criteria and were therefore included in the analysis. Generic richness herein is represented by actual occurrences using a rangethrough approach in one million-year time bins. The time bins start at $45.5 \mathrm{Ma}$ and end at 0.5 Ma. The upper limit of a bin is included, and the lower limit is excluded. For more sophisticated data standardisations, readers are directed to an excellent review about sampling bias and data standardisations for biodiversity by Aberhand and Kiessling (2012) and references therein. Tooth terminology follows Emry et al. (1997).

\begin{tabular}{|c|c|}
\hline \multicolumn{2}{|c|}{ Abbreviations } \\
\hline $\mathrm{MN}$ & $\begin{array}{l}\text { Mammal Neogene zone for European land } \\
\text { mammal age }\end{array}$ \\
\hline MP & $\begin{array}{l}\text { Mammal Paleogene zone for European land } \\
\text { mammal age }\end{array}$ \\
\hline $\mathrm{M}$ or $\mathrm{m}$ & $\begin{array}{l}\text { Molar, the upper case for the upper dentition } \\
\text { and the lower case for the lower dentition }\end{array}$ \\
\hline $\mathrm{P}$ or $\mathrm{p}$ & $\begin{array}{l}\text { Premolar, the upper case for the upper dentition } \\
\text { and the lower case for the lower dentition }\end{array}$ \\
\hline IVPP & $\begin{array}{l}\text { Institute of Vertebrate Paleontology and } \\
\text { Paleoanthropology, Beijing, China }\end{array}$ \\
\hline IZ NAS RK & $\begin{array}{l}\text { Institute of Zoology, National Academy of } \\
\text { Sciences, Republic of Kazakhstan }\end{array}$ \\
\hline NHMW & $\begin{array}{l}\text { Museum of Natural History Vienna, Vienna, } \\
\text { Austria }\end{array}$ \\
\hline NMNS & $\begin{array}{l}\text { National Museum of Nature and Science, } \\
\text { Tokyo, Japan }\end{array}$ \\
\hline
\end{tabular}

\section{Systematic palaeontology}

A total of 47 eomyid genera have been described to date. Of these, fourteen genera are reported from Asia, and half of them are endemic to Asia or only known from the type locality. In this section, we review the Asian eomyids, especially focusing on the endemics with a brief description of diagnostic dental traits, locality occurrences (Text-fig. 1), and stratigraphic ranges (Text-fig. 2). The taxonomic data were newly compiled along with geological and biostratigraphical information in Appendix, which were also used to explore the eomyid diversity patterns in Asia in the last part of this study.

\author{
Family Eomyidae WINGE, 1887 \\ Subfamily Eomyinae WINGE, 1887 \\ Tribe Eomyini Winge, 1887
}

\author{
Genus Symplokeomys Emry, WAng, TuUTKova \\ et LuCAS, 1997 \\ Text-figs 1-3
}

Type species. Symplokeomys zaysanicus EMry, WANG, TuUtKova et LuCAs, 1997.

Included Asian species. The type and only species.

Dental characteristics. Medium-sized eomyid, apparently retaining P3 as in Yoderimyinae; branching mesoloph(id) and interconnecting lophules in synclines/ synclinids II and III, forming complex bunolophodont patterns; no lingual part of the anteroloph; hypolophid connecting to posterolophid; presence of spurs in transverse loph(id)s.

A sian occurrences ( a g e ). For the type and only species, locality K10 in Zaysan Basin, Sunduk, Kazakhstan (Aksyir Formation, Ergilian, late Eocene).

Comments. The genus is peculiar compared to any other known eomyids in having extremely complex occlusal patterns with interconnecting lophules in synclines/ synclinids II and III as well as retaining P3 as in the subfamily Yoderimyinae (Emry et al. 1997). The authors note that the presence of $\mathrm{P} 3$ is a primitive condition in the Eomyidae and was independently retained in Symplokeomys. Phylogenetic relationships of Symplokeomys with other eomyids have not been resolved.

\section{Genus Asianeomys Wu, Meng, Ye et Ni, 2006 Text-figs 1, 2, 4}

Type species. Asianeomys junggarensis Wu, Meng, Ye et Ni, 2006.

Included A sian species. Asianeomys junggarensis, Asianeomys asiaticus, Asianeomys dangheensis, Asianeomys fahlbuschi, Asianeomys yanshini, Asianeomys engesseri. Asianeomys engesseri could be a junior synonym of $A$. fahlbuschi according to Qiu and Li (2016). Note that "Eomyodon" bolligeri from Kazakhstan possibly belongs to the genus Asianeomys (Maridet et al. 2015).

Dental characteristics. Bunolophodont; small to medium-sized eomyid; P4 with or without anteroloph; entoloph connecting to the posterior end of the protocone rather than protoloph, differing from Pseudotheridomys, so that the syncline II is longer than the syncline I; three-rooted p4 lacking anteroconid; four roots on $\mathrm{m} 1-\mathrm{m} 2$; hypolophid connecting to the anterior arm of the hypoconid, differing from more posterior connection in Eomys; mesoloph(id) usually long; hypolophid present on m3 (Wu et al. 2006, Qiu and Li 2016).

A sian occurrences ( a g e). For A.junggarensis, localities XJ98035, XJ98024, XJ200209, Tieersihabahe of North Junggar Basin, China (Tieersihabahe mammal assemblage zone I, late Oligocene, 24.4 to 23.2 Ma by Meng 


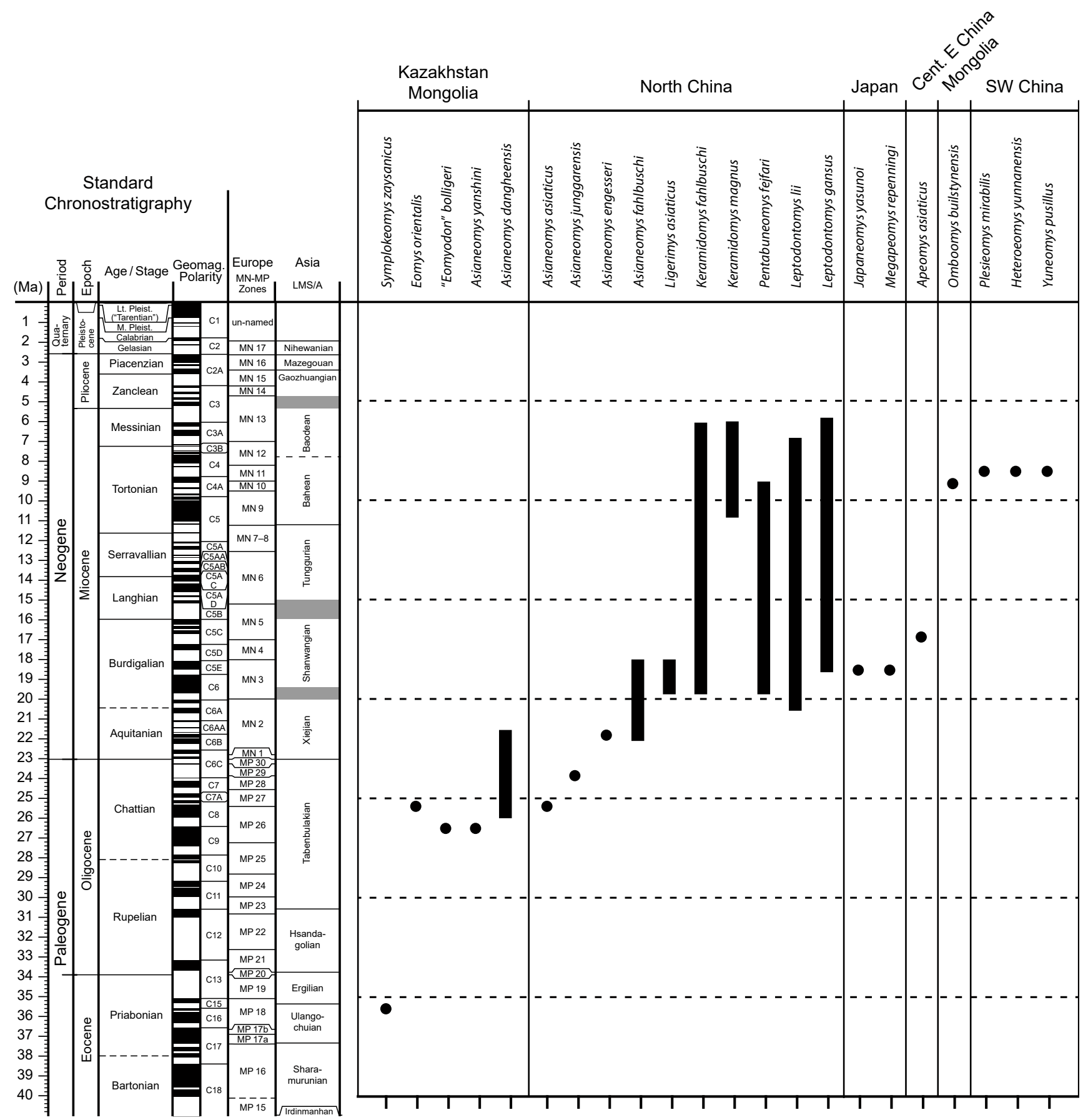

Text-fig. 2. Stratigraphic range of Asian eomyids based on "range-through" occurrences. Standard chronostratigraphy was built in TimeScale Creator version 7.3 (https://engineering.purdue.edu/Stratigraphy/tscreator/index/index.php), which is based on the GTS 2016 age model. For mammalian biochronology, European Neogene Mammal (MN) unit and Paleogene Mammal (MP) unit as well as the Asian land mammal ages in the Paleogene were also downloaded from TimeScale Creator version 7.3. Neogene Chinese land mammal stage/ages (LMS/A) are based on Qiu and Li (2016).

et al. 2006) (Wu et al. 2006). For A. dangheensis, locality XJ99005, North Junggar Basin, China (Suosuoquan Mammal assemblage zone II, early Miocene, 21.9 to 21.7 Ma by Meng et al. 2006) (Wu et al. 2006); 6 different sections (Del, Huch Teeg, Tatal Gol, Unkheltseg, Luuny Yas, Hotuliin Teeg) within $660 \mathrm{~km}^{2}$ in Central Mongolia (Valley of Lakes) (Loh Formation, local biozones C1, C1/D, D, late Oligocene to early Miocene, 25.6 to $21 \mathrm{Ma}$ by Daxner-Höck et al. 2017) (Maridet et al. 2015); IVPP Loc. DH199904, Aksay Kazak Autonomous County, Gansu, China (Paoniuquan Formation, Tabenbulukian, 28.4 to $23 \mathrm{Ma}$ ) (Wang 2002, Wang et al.
2008). For A. fahlbuschi, locality XJ99005, North Junggar Basin, China (Suosuoquan mammal assemblage zone II, early Miocene, 21.9 to $21.7 \mathrm{Ma}$ by Meng et al. 2006) (Wu et al. 2006); two sites located $40 \mathrm{~km}$ apart in central Inner Mongolia, China, Aoerban and Gashunyinadege in stratigraphic order (the lower red member of the Aoerban Formation to Gashunyinadege bed, late Xiejian to early Shanwangian, correlated to MN 2-MN 3, 21.7 to 17.2 Ma) (Qiu and Li 2016). For A. asiaticus, IVPP Loc. 77048, Saint Jacques, Inner Mongolia, China (Wulangulage Formation, late Oligocene, 27.8 to $23 \mathrm{Ma}$ ) (Wang and Emry 1991). For 

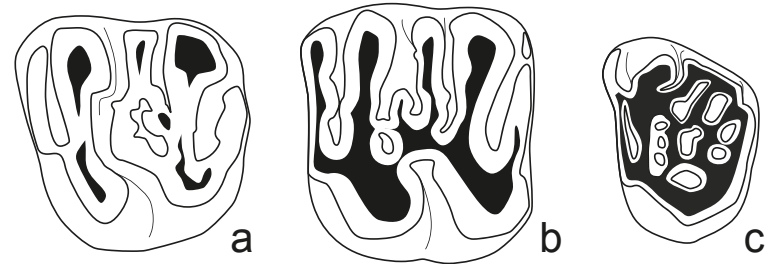

$1 \mathrm{~mm}$
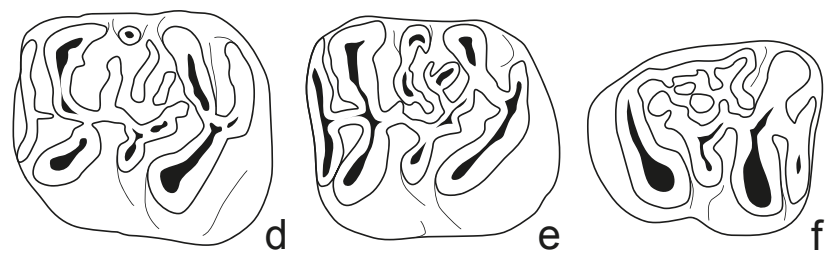

Text-fig. 3. Symplokeomys zaysanicus EMry, Wang, TuUtkova et LuCAS, 1997 from type locality. a: left P4 (IZ NAS RK 35 (10)/1829), b: left M1 or M2 (IZ NAS RK 35 (10)/1831), c: left M3 (IZ NAS RK 35 (10)/1836), d: left m1 (IZ NAS RK 35 (10)/1843, holotype), e: left m2 (IZ NAS RK 35 (10)/1845), f: right m3 (IZ NAS RK 35 (10)/1853). A scale equals to $1.0 \mathrm{~mm}$.

A. yanshini, Altynshokysu locality, Aktyubinsk, Kazakhstan (Aral Formation, correlated with the Central Mongolian local biozone C, $\sim 27.4$ to $\sim 25.6 \mathrm{Ma}$, by Bendukidze 2009) (Lopatin 2000). For A. engesseri, locality XJ99005, North Junggar Basin, China (Suosuoquan mammal assemblage zone II, early Miocene, 21.9 to $21.7 \mathrm{Ma}$ by Meng et al. 2006) (Wu et al. 2006). For $A$. aff. engesseri, locality XJ200604, northern Xinjiang province, China (age close to
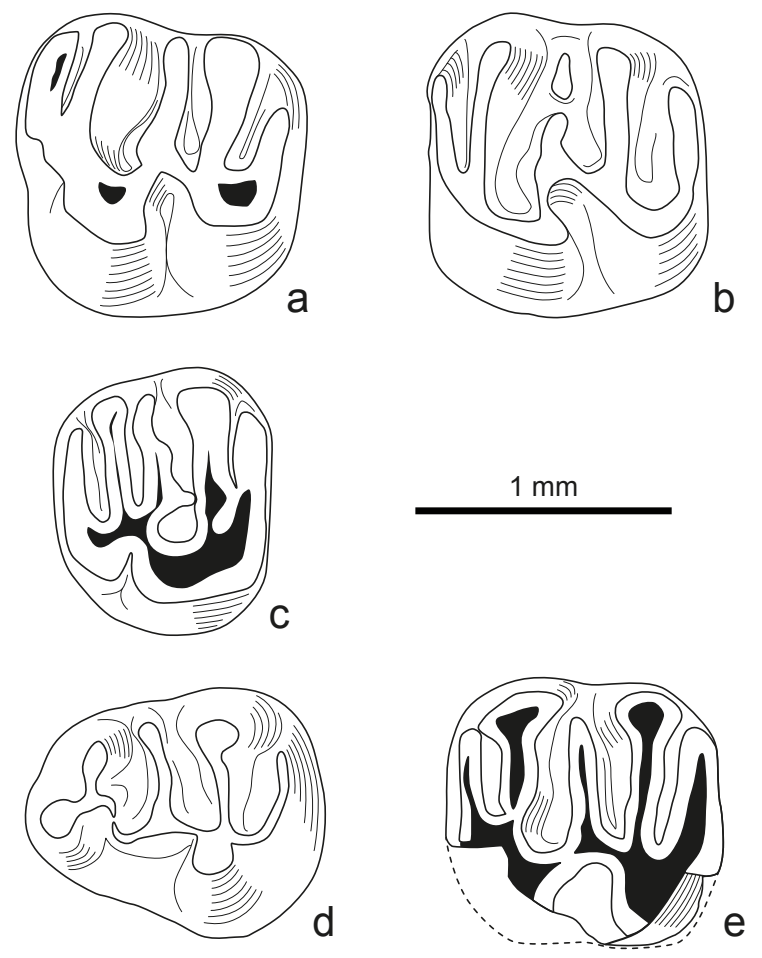

Text-fig. 4. Asianeomys junggarensis Wu, Meng, YE et NI, 2006 from type locality. a: left P4 (IVPP V14452.2, paratype), b: left M1/2 (IVPP V 14452.1, holotype), c: right M3 (IVPP V14454.1), d: left p4 (IVPP V14452.5, paratype), e: left m1/m2 (IVPP V14453.2). A scale equals to $0.5 \mathrm{~mm}$.
Sihong and Gashunyinadege localities, late early Miocene, $\sim 17$ to $\sim 18$ Ma, Deng 2006) (Maridet et al. 2011). For cf. Asianeomys bolligeri, 2 different sections within $10 \mathrm{~km}$ in central Mongolia (Valley of Lakes) (Local biozone C, late Oligocene, $\sim 27.4$ to $\sim 26.5$ Ma by Daxner-Höck et al. 2017) (Maridet et al. 2015). For "Eomyodon" bolligeri from Kazakhstan, North Aral Region (Altyn shokysu locality, bone bed I and II, Aral Formation, late Oligocene, correlated with the Central Mongolian local biozone C, $\sim 27.4$ to $\sim 25.6$ Ma by Bendukidze 2009) (Lopatin 2000).

Comments. Wu et al. (2006) erected the genus Asianeomys for material from the Junggar Basin in Xinjiang, North China. They transferred all Asian species of eomyid rodents known at the time to the new genus: two species of Pseudotheridomys ("P." asiaticus, "P." yashini) and one species of Eomyodon ("E." dangheensis). The Asian occurrence of Pseudotheridomys (particularly, "P." asiaticus, slightly earlier than the European occurrence of the genus) was once considered to be possible evidence for Asian origin of the genus (Korth 2008), but currently no valid species of Pseudotheridomys is reported from Asia. Because Asianeomys has Eomys-like upper dentition and Pseudotheridomys-like lower dentition, it is difficult to properly identify the genus when only small samples are available. To date, Asianeomys has been reported from North China, Mongolia, and Kazakhstan. The genus is more closely related to Keramidomys than Pseudotheridomys based on dental similarity to a basal species Keramidomys, K. fahlbuschi, recently discovered in Inner Mongolia, China (Qiu and Li 2016, Kimura et al. 2019).

\section{Genus Eomys Schlosser, 1884}

Comments. Eomys orientalis is the only Asian species of Eomys. It was first discovered from the Oligocene of Inner Mongolia, China (Wang and Emry 1991). Wang and Emry (1991) pointed out that E. orientalis is similar to European Eomys in the more lingually extended synclines, whereas the species is also similar to North American Adjidaumo in having a weakly developed synclinid IV. Overall, Eomys orientalis is most similar to E. antiquus, which represents the earliest occurrence (early Oligocene, MP 21) of the family in Europe (Maridet et al. 2010). Until recently, the record of Asian Eomys had been limited to the type locality with a handful of specimens described in Wang and Emry (1991). However, Maridet et al. (2015) recently reported new material provisionally assigned to Eomys cf. orientalis from the early Oligocene of Central Mongolia.

\section{Genus Keramidomys Hartenberger, 1966}

Comments. Two species are known from Asia: K. fahlbuschi Qıu, 1996 and K. magnus Qıu et Li, 2016 (see Appendix). Keramidomys has been reported from multiple localities within an area of $13,000 \mathrm{~km}^{2}$ in central Inner Mongolia, China. In addition, few specimens were found in Siberia (Russia), Valley of Lakes (Mongolia), and Xinjiang (China) (Appendix 1). The stratigraphic range of the genus is as long as that of cosmopolitan Leptodontomys in Asia, ranging from the Xiejian (correlated to MN $2-\mathrm{MN} 3,21.7$ to $17.2 \mathrm{Ma}$ ) to Baodean (correlated to MN $12-\mathrm{MN} 13$, 
7.4 to $5.3 \mathrm{Ma}$ ), geologically from the Aoerban Formation and Gashunyinadege bed to the Bilutu bed, represented by K. fahlbuschi (Qiu and Li 2016). The other species known from the region is $K$. magnus, which presents a shorter range than $K$. fahlbuschi, recorded in late Miocene local faunas equivalent in age to MN 9 to MN 13. Keramidomys is thought to have originated in East Asia and later dispersed into Europe (Mein 2009), considering the earlier occurrence of Asian $K$. fahlbuschi, which is generally less lophodont than European species (Qiu and Li 2016, Kimura et al. 2019). It first appears in the European record at MN 5 (Mein 2009), which postdate the regional climax of the eomyid diversity.

\section{Genus Leptodontomys SHOTwell, 1956 or Eomyops EngESSER, 1979}

C o m m e n t s. The genera Eomyops and Leptodontomys may be synonyms. Many different European species had been long assigned to the North American genus Leptodontomys until Engesser (1979) erected the new genus Eomyops for the European forms which differ from Leptodontomys in details of the mandible morphology and the presence of two ridges on the enamel of the lower incisors. Yet, the validity of Eomyops has been questioned and is still debated because cheek teeth of both genera are remarkably similar (Qiu 1994, de Bruijn et al. 2012). Generally, Asian species are ascribed to Leptodontomys (Qiu and $\mathrm{Li}$ 2016) or Leptodontomys/Eomyops (Maridet et al. 2015) until lower incisors of Asian species are found to clarify their taxonomic attribution.

Two species are known from Asia: Leptodontomys gansus Zheng et Li, 1982 and L. lii Qiu, 1996 (Text-fig. 2, Appendix). Leptodontomys gansus was the first eomyid to be discovered in Asia (Zheng and Li 1982) and is represented by a right mandible with a complete set of cheek teeth. Later on, more specimens of the same species were discovered from nine localities in large areas within $32,500 \mathrm{~km}^{2}$ in central Inner Mongolia, China (Qiu and Li 2016), stratigraphically ranging from the Aoerban Formation and the Gashunyinadege bed (correlated to MN $2-\mathrm{MN} \mathrm{3,21.7} \mathrm{to} 17.2 \mathrm{Ma}$ ) to the Ertemte Formation (correlated to $\mathrm{MN} \mathrm{13,} 7.1$ to $5.3 \mathrm{Ma}$ ). Leptodontomys lii was first found from the middle Miocene Moergen II locality in central Inner Mongolia, China (Qiu 1996), and later additional materials were found from older and younger deposits in the same areas, mostly overlapping with the stratigraphic occurrences of L. gansus except for the late late Miocene Ertemte2 and Harr Obo2 localities, where the latter species are present. Leptodontomys lii is similar in dental morphology to L. gansus but is distinguishable by larger tooth size with more bulbous main cusps and more pronounced mesoloph(id) with slightly higher crown (Qiu and $\mathrm{Li}$ 2016). A fossil of Leptodontomys/Eomyops sp. was also found in the local biozone D1/2 (late early Miocene) in Mongolia (Maridet et al. 2015). A small $\mathrm{m} 1 / \mathrm{m} 2$ fossil found in Olkhon Island (Lake Baikal, Siberia) was assigned to Eomyops oppligeri ENGESSER, 1990 based on its size and morphology (Daxner-Höck et al. 2013). However, the taxonomic assignment should be reconsidered because the fossil is also within the size range of and is comparable in morphology to Leptodontomys gansus as shown in fig. 72: I of Qiu and Li (2016).
Qiu (1994) noticed that middle to late Miocene Chinese Leptodontomys are intermediate between North American Leptodontomys and European Eomyops in dental traits on the lower molars and mandible shape. Therefore, Qiu (1994) suggested European Eomyops was derived from North American Leptodontomys species that dispersed through Asia although the first appearance of Chinese Leptodontomys in Tunggur (late middle Miocene), Inner Mongolia, was younger than the first appearance of European Eomyops (then, dated to the earliest middle Miocene, MN 5) when his study was published. Currently, fossils of Asian Leptodontomys have been discovered from early Miocene deposits such as the lower red member of the Aoerban Formation and the Gashunyinadege bed, correlated to $\mathrm{MN} 2-\mathrm{MN} 3$, in Inner Mongolia, China (Qiu and Li 2016), and thus significantly older than the first European record of Eomyops, MN 4 of Morteral-20 A in Valencia, Spain (Ruiz-Sánchez et al. 2009). Owing to the series of discoveries in Inner Mongolia, Leptodontomys along with Keramidomys are the longest-ranging eomyids in Asia (and the same is true for Europe; see Engesser 1999).

\section{Genus Pentabuneomys Engesser, 1990}

Comments. The genus Pentabuneomys included a single species from Europe (Pentabuneomys rhodanicus (Hugueney and Mein 1968); MN 3 to MN 4, early Miocene) and another from North America (P. engesseri KorTh, 2008, early Arikareean, late Oligocene) until the discovery of Pentabuneomys fejfari, which is currently its only Asian representative (Qiu and Li, 2016). Pentabuneomys fejfari was described based on the total of nearly 40 specimens from the early Miocene Lower Aoerban fauna/Gashunyinadege fauna (correlated to MN $2-\mathrm{MN} 3$ ) and the late Miocene Amuwusu fauna (correlated to MN 9). Pentabuneomys was erected by Engesser (1990) to separate European "Eomys" rhodanicus from other Eomys species. Pentabuneomys differs from Eomys in having bulbous cusps with a large circular mesocone/mesoconid and the presence of a deeper valley between the hypolophid and the posterior cingulum (Engesser 1990, Korth 2008). Korth (2008) reported the first record of Pentabuneomys from North America. The North American species, $P$. engesseri is not only chronologically older but also more plesiomorphic than European $P$. rhodanicus in completely lacking the mesolophid and the ectolophid. Thus, it could be possible that the genus originated in North America and later dispersed into Europe through Asia in the late Oligocene to early Miocene. Korth (2008) suggested that Pentabuneomys was derived from a Leptodontomys-like ancestor with reduced lophs in cheek teeth. Qiu and Li (2016) also discussed the similarity between Leptodontomys/Eomyops and Pentabuneomys to suggest that Asian P. fejfari is intermediate in occlusal morphology between European Eomyops hebeiseni and Pentabuneomys rhodanicus. The phylogenetic relationships of Pentabuneomys in relation to the genera mentioned above is still uncertain.

\section{Genus Ligerimys Stehlin et Schaub, 1951}

Comments. Three specimens from early Miocene localities (equivalent to MN 2 - MN 3) in Inner Mongolia 
(China) were assigned to the first Asian species of Ligerimys: L. asiaticus, which is larger than other species of Ligerimys (Qiu and Li 2016). In addition to the diagnostic traits mentioned by Qiu and Li (2016), the Asian species is characterized by the synclinid II closed by the posterior extension of longituidinally elongated metaconid. Ligerimys is considered to be derived from Pseudotheridomys (Escarguel and Aguilar 1997, Engesser 1999) and was considered to be endemic to Europe before L. asiaticus was discovered in Inner Mongolia. More specimens are necessary to understand the phylogenetic relationships of this species and closely related taxa.

\section{Genus Japaneomys Kimura, Tomida, Kalthoff, Casanovas-Vilar et Mörs, 2019 Text-figs 1, 2, 5}

Type species. Japaneomys yasunoi KIMURA, Tomida, Kalthoff, Casanovas-Vilar et Mörs, 2019.

Included Asian species. The type and only species.

Dental characteristics. Characters shared with Asianeomys, Keramidomys, and Estramomys are four roots in $\mathrm{m} 1$ and the hypolophid anteriorly connecting to the anterior arm of hypoconid. More bunodont with lower lophids than the genera listed above, yet transverse lophids complete; small eomyid, similar in size to Keramidomys; two rooted p4 (rather than three roots as in all species of Asianeomys except A. junggarensis); anterior lobe narrower than posterior lobe on $\mathrm{m} 1$ (correspondingly, synclinid I of $\mathrm{m} 1$ much shallower and shorter than half the length of synclinid IV); hypolophid anteriorly concave on $\mathrm{m} 1$ (Kimura et al. 2019).

Asian occurrences (age). For the type and only species, Dota Town, Kani City, Gifu Prefecture, central Japan (near the uppermost level of the Nakamura Formation, Mizunami Group; age estimated to be around $18.5 \mathrm{Ma}$ ) (Kimura et al. 2019).

Comments. The genus Japaneomys was erected based on a right mandible with $\mathrm{p} 4$ and $\mathrm{m} 1$ discovered from the early Miocene of central Japan (Kimura et al. 2019). An ml of Megapeomys was also discovered in the same locality (Tomida 2011). The jaw was originally ascribed to Pseudotheridomys sp. (Tomida and Setoguchi 1994) but later Tomida (2011) noted its morphological similarities with Keramidomys. However, Japaneomys retains plesiomorphic dental traits compared to contemporaneous eomyids such as Keramidomys (Kimura et al. 2019). Phylogenetic analyses have revealed that Japaneomys diverged earlier than Asianeomys and Keramidomys in the late Oligocene, when Japan was part of the coastal margin of East Asia. We suggest that some degree of geographic isolation existed at that time, thus separating certain lineages of small mammals in the coastal region from those in inner-continental regions of Asia.

\section{Genus Omboomys Maridet, Daxner-Höck, Badamgarav et GöHLICH, 2015 Text-figs 1, 2, 6}

Ty pe s pecies. Omboomys builstynensis MARIDET, DAXNER-Höck, BADAMGARAV et GöHLICH, 2015.
Included Asian species. The type and only species.

Dental characteristics. Small-sized bunodont eomyid. It is clearly smaller than other Asian endemic genera such as Asianeomys and Heteroeomys and slightly smaller than Japaeomys. Characterized by a slender morphology and a low crown, but with cusp(id)s noticeably higher than the mid-portion of the tooth in antero-posterior view. Other noticeable characteristics are upper teeth missing mesoloph, whereas in lower teeth the mesolophid is rare and weakly developed (thus, the molars only have three syncline(id)s with the central one being much wider and larger than the others). M1/2 with trapezoidal outline and oblique, short longitudinal crest joining directly the metaloph to the posterior end of the protocone. p4s with oblique longitudinal crest joining the hypoconid with the metalophid or with the metaconid (but never with the protoconid).

Asian occurrences (age). For the type and only species, locality Builstyn Khudag, Mongolia (Tuyn Gol Formation, local biozone E, late Miocene, younger than $13 \mathrm{Ma})$.

Co m m e n t s. Late Miocene Omboomys is an endemic eomyid genus in the late Miocene of northeastern Asia. However, the origin of Omboomys is unknown due to the lack of an intermediate fossils between the late early Miocene and the late Miocene in the Valley of Lakes in Mongolia (DaxnerHöck et al. 2017). The general bunodont morphology, the small size and low crown along with the trapezoidal shape of the $\mathrm{M} 1 / 2$, and the curved longitudinal crest connecting to the protocone in $\mathrm{P} 4-\mathrm{M} 1 / 2$ suggest its closer phylogenetic affinity to Leptodontomys/Eomyops than any other genus of Eomyidae known in the Miocene of Eurasia. The disappearance of the mesoloph(id)s is also observed in other eomyid clades in the Miocene of Europe such as the Rhodanomys-Ritteneria clade or the Keramidomys-Estramomys clade (Engesser 1990, 1999). Considering the more likely affinity of Omboomys with Leptodontomys/Eomyops, the disappearance of the mesoloph[id]s seems to be a convergent evolution, resulting from a local evolutionary history leading to Omboomys in northeastern Asia.

\section{Genus Heteroeomys QIU, 2006} Text-figs $1,2,7$

Ty p e s pe c i e s. Heteroeomys yunnanensis QIU, 2006.

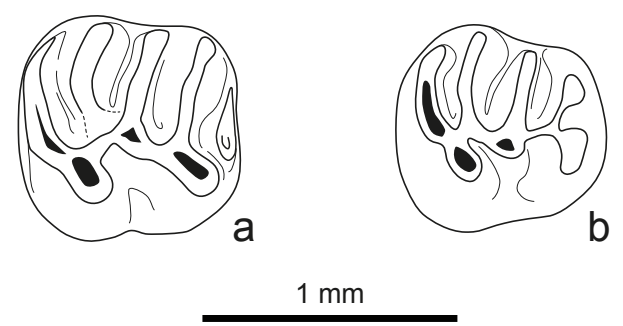

Text-fig. 5. Japaneomys yasunoi KIMURA, Tomida, KALTHOFF, Casanovas-Vilar et Mörs, 2019 from type locality. a: right m1 (NMNS-PV19995, holotype), b: right p4 (NMNS-PV19994, paratype). Note that specimens were labelled reversely by mistake in the original literature. A scale equals to $0.5 \mathrm{~mm}$. 

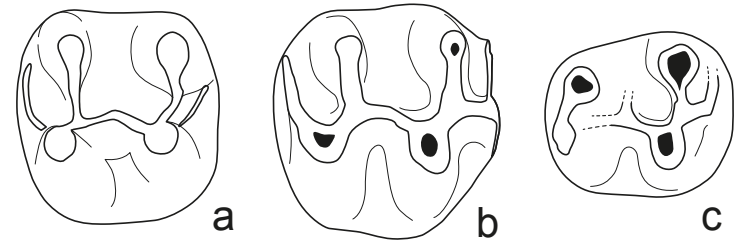

$1 \mathrm{~mm}$
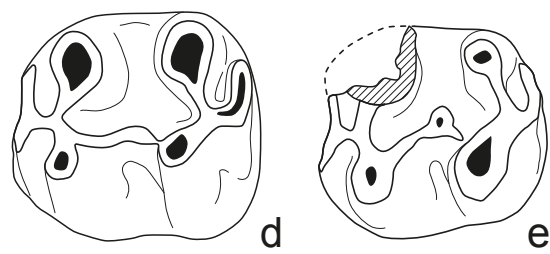

Text-fig. 6. Omboomys builstynensis MARIDET, DaXner-Höck, BaDAMgaRaV et GöHLICH, 2015 from type locality. a: right P4 (NHMW 2013/0076/0002), b: right M1/2 (NHMW 2013/0076/0004, holotype), c: left p4 (NHMW 2013/0076/0009), d: left m1/2 (NHMW 2013/0076/0013), e: left m3 (NHMW 2013/0076/0014). A scale equals to $0.5 \mathrm{~mm}$.

Included Asian species. The type and only species.

Dental characteristics. Bunodont; mediumsized eomyid, similar in size to Asianeomys, slightly larger than Plesioeomys and within large size variation of Eomyops. Plesiomorphic features include mesoloph(id) of moderate length; main cusps asymmetrically developed between the labial and lingual sides; weak anterolophid shorter than metalophid; weak ectolophid; protoloph and metaloph directed more perpendicular than in Pseudadjidaumo. Derived features comprise relatively higher crown, anteroloph extending far lingually and connecting directly to the protocone without the lingual part of protocone, which is unique among any known eomyid genera (modified from Qiu 2006).

Asian occurrences (age). For the type and only species, locality Shihuiba, Lufeng, Yunnan Province, China (Shihuba Formation, late Miocene, not well dated but see Flynn and Qi 1982, Ni and Qiu 2002, Appendix); Leilao, Yuanmou, Yunnan Province, China (Xiaohe Formation, early Baodean, biostratigraphically around 9 Ma by Flynn and Qi 1982, Ni and Qiu 2002).

$\mathrm{C}$ o $\mathrm{m}$ m e $\mathrm{n} \mathrm{t} \mathrm{s}$. Eomyid rodents were only reported from the modern Palaearctic realm until a series of finds in the late Miocene hominoid localities, Shihuiba and Leilao, Yunnan Province in southwestern China, which is part of the modern Oriental realm (Qiu 2006) (Text-fig. 1). The Yunnan eomyids are represented by three endemic genera with bunodont tooth patterns: Heteroeomys, Plesieomys, Yuneomys. They not only demonstrate that eomyids were distributed in tropical forest environments of Asia but also suggest regionally unique evolutionary histories of Asian eomyid rodents with several intercontinental dispersals. Qiu (2006) pointed out that Asian eomyids in the northern region have more lophodont tooth patterns than those in the southern region, reflecting different vegetation types with more open environments in the north. The Yunnan eomyids are similar in dental traits to North American Pseudadjidaumo and Leptodontomys/
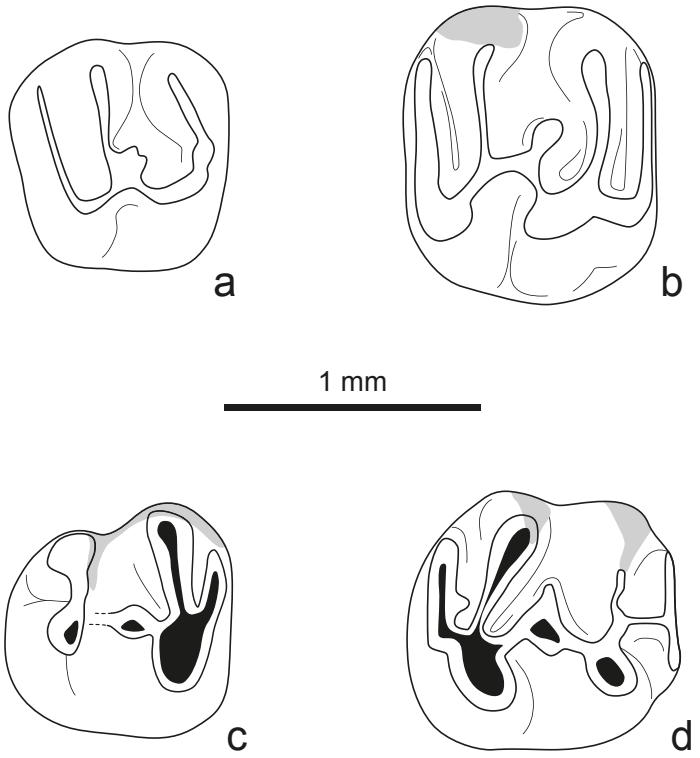

Text-fig. 7. Heteroeomys yunnanensis Qiv, 2006 from type locality. a: right P4 (IVPP V 14730.3), b: right M1/2 (IVPP V 14729, holotype), c: left p4 (IVPP V 14731.5), d: right m1/2 (IVPP V 14731.6). A scale equals to $0.5 \mathrm{~mm}$.

Eomyops. However, phylogenetic relationships among these genera remain unknown.

\section{Genus Plesieomys Qıu, 2006}

Text-figs 1, 2, 8

Ty pe s pe cies. Plesieomys mirabilis Qıu, 2006.

Included Asian species. The type and only species.

Dental characteristics. Bunodont; relatively small eomyid, similar in size to Pseudadjidaumo and within large size variation of Eomyops; main cusps symmetrically developed; lingual portion of the anteroloph greatly reduced; anteroloph weakly developed; syncline II longer than other synclines; mesolophid of medium length with minute terminal cuspule present; metaloph poorly developed; lingual syncline symmetrical; short anterolophid connecting to metalophid through a longituidinal crest; hypolophid variably absent or interrupted (modified from Qiu 2006).

Asian occurrences (age). For the type and only species, locality Shihuiba, Lufeng, Yunnan Province, China (Shihuiba Formation, late Miocene, not well dated but see Flynn and Qi 1982, Ni and Qiu 2002, Appendix); Leilao, Yuanmou, Yunnan Province, China (Xiaohe Formation, early Baodean, biostratigraphically approximately $9 \mathrm{Ma}$ after Flynn and Qi 1982, Ni and Qiu 2002).

C o m m e n t s. Qiu (2006) pointed out that Plesieomys is morphologically similar to Pseudadjidaumo in cusp size, weakly developed loph(id)s, and closed synclines I and IV. The Yunnan specimens were assigned to a new genus because loph(id)s are less developed than in Pseudadjidaumo, which is known from the Mojave Desert in North America (Lindsay 1972). In Plesieomys, a mesoloph enlarged at the terminal point is considered to be a diagnostic trait. 

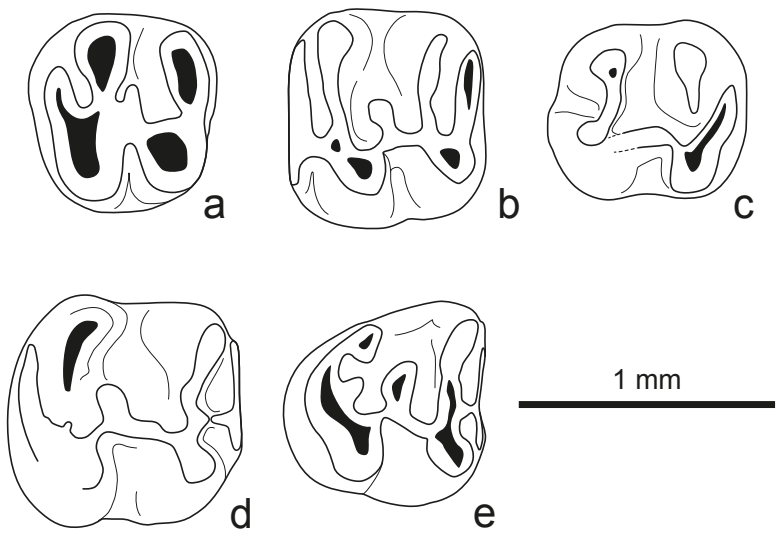

Text-fig. 8. Plesieomys mirabilis QIU, 2006 from type locality. a: right P4 (IVPP V 14727.1), b: left M1/2 (IVPP V 14726, holotype), c: left p4 (IVPP V 14727.4), d: right m1/2 (IVPP V 14728.3), e: right $\mathrm{m} 3$ (IVPP $V$ 14727.11). A scale equals to $0.5 \mathrm{~mm}$.

Prieto (2012) noted that the enlarged termination of the mesoloph is present in European species of Eomyops such as E. noelinae (Ruiz-Sánchez et al. 2009) and also variably present in E. catalaunicus from German localities (Prieto 2012). In fact, the upper dentition of Plesieomys seems to be indistinguishable from that of Eomyops. Maridet et al. (2015) also pointed out this similarity and briefly stated the possible synonymy of Plesieomys, as well as Heteroeomys from the same locality, to Leptodontomys/Eomyops. Here, we retain the genus Plesieomys, considering the hypolophid being absent or indistinct as a diagnostic trait at the generic level. However, a detailed review of Asian material in comparison with European Eomyops is required to clarify the validity of this genus.

\section{Genus Yuneomys Qiv, 2017 \\ Text-figs $1,2,9$}

Type species. Yuneomys pusillus (QIU, 2006).

Included Asian species. The type and only species.

Dental characteristics. Bunodont; small eomyid, smaller or equivalent in size to Leptodonomys and Eomyops; short mesoloph; complete entoloph; small mesoconid; anterolophid connecting to the metalophid through a longitudinal crest at the midline of the tooth. Differing from the above genera in having $\mathrm{m} 1 / 2$ with metalophid and hypolophid less developed, short, and directed transversely; symmetrical arrangement of cuspids and lophids between the anterior and posterior lobes (i.e., metaconid, protoconid, anterolophid vs. entoconid, hypoconid, posterolophid); mesolophid absent (modified from Qiu 2017; this study).

Asian occurrences (age). For the type and only species, locality Shihuiba, Lufeng, Yunnan Province, China (Shihuiba Formation, late Miocene, not well dated but see Flynn and Qi 1982, Ni and Qiu 2002, Appendix).

$\mathrm{Comments}$. The genus was originally described as a new species of Leptodontomys (Qiu 2006). However, it was
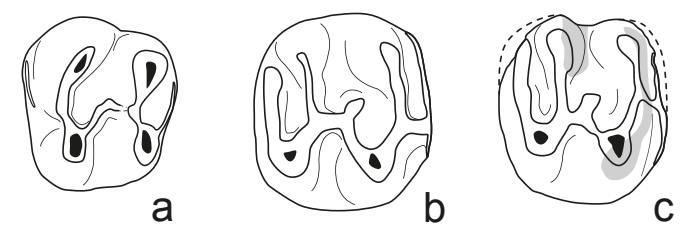

$1 \mathrm{~mm}$
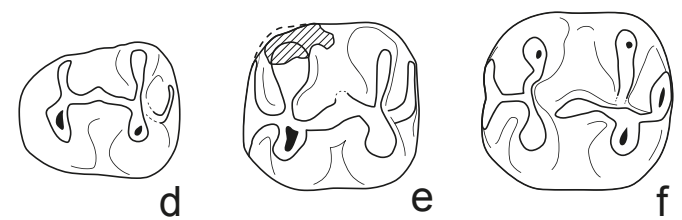

Text-fig. 9. Yuneomys pusillus (QIU, 2006) from type locality. a: left P4 (IVPP V 14733.4), b: right M1/2 (IVPP V 14732, holotype), c: right M1/2 (IVPP V 14733.1), d: left p4 (IVPP V 14733.5), e: left $\mathrm{m} 1 / 2$ (IVPP V 14733.2), f: left $\mathrm{m} 1 / 2$ (IVPP $\mathrm{V}$ 14733.6). A scale equals to $0.5 \mathrm{~mm}$.

later transferred to a newly erected genus, Yuneomys (Qiu 2017). Thus, all of the Yunnan eomyid genera (Heteroeomys, Plesieomys, Yuneomys) are endemic to southwestern China although they are morphologically similar to Eomyops and Leptodontomys. Scarce specimens of Yuneomys preclude accurate differential diagnosis, particularly in comparison with Eomyops and Leptodontomys, which show considerable variation in cheek tooth morphology. The upper dentition of Yuneomys is in fact identical to that of the two genera. Here, we tentatively retain Y. pusillus encased in Yuneomys. Nevertheless, as stated above, we suggest that the validity of Yuneomys and Plesieomys should be reexamined, particularly taking into account the large variation in Eomyops and Leptodontomys.

\section{Subfamily Apeomyinae FeJfar, Rummel et Tomida, 1998}

Comments. The subfamily Apeomyinae, which contains Apeomys, Megapeomys, Apeomyoides, and Arikareeomys is known based on extremely scarce materials and is restricted to the late Oligocene and early Miocene (Fahlbusch 1968, Korth 1992, Engesser 1999, Smith et al. 2006, Flynn 2008, Mörs and Flink 2018). Nevertheless, apeomyine eomyids are Holarctic in distribution, occurring in Europe (Apeomys, Megapeomys), North America (Megapeomys, Apeomyoides, Arikareeomys), and Asia (Apeomys, Megapeomys).

\section{Genus Megapeomys Fejfar, Rummel et Tomida, 1998}

Comments. Megapeomys is phylogenetically closest to Apeomys (Engesser 1999). In the Asian record Megapeomys is as scarce as Apeomys and may predate it slightly. A single species of Megapeomys, M. repenningi, was described in Asia based on a single tooth from the early Miocene of central Japan (Fejfar et al. 1998, Tomida 2011). Tomida (2011) noted that $M$. repenningi resembles contemporaneous European $M$. lavocati in occlusal morphology, but the former species is more basal in having a distal root unsplit. According to Mörs and Flink (2018), M. repenningi is similar in size to a second and larger European species, M. lindsayi, which is morphologically 
similar to M. lavocati. The single North American species of Megapeomys, M. bobwilsoni, is larger and more hypsodont, and the distal root is completely split into two separate roots.

\section{Genus Apeomys Fahlbusch, 1968}

C o m ments. In Asia, a high-crowned P4 specimen was discovered in 1994 from the late early Miocene Xiacaowan Formation in Sihong, Jiansu Province, central East China. It was recently identified as the only Asian species of Apeomys, A. asiaticus QIU, 2017 (Text-fig. 2, Appendix). Compared to European $A$. tuerkheimae and $A$. oldrichi, Asian A. asiaticus has more derived dental features such as the anteroloph fused with the protoloph, absence of the mesoloph, and the closed syncline III (Qiu 2017).

\section{Biogeographic significance of Asian eomyids}

Over the past two decades, more and more eomyid fossils have been discovered in East Asia and the Asian part of Russia. To date, 22 species within 14 genera were reported from Asia, including seven endemic genera and rare material of apeomyine eomyids from southwestern China and Japan (Text-fig. 2). The total number of eomyid genera in Asia is now equivalent to that in Europe. For most of the endemic genera, phylogenetic relationships and their evolutionary history are of high interest but remain uncertain. On the other hand, the other seven non-endemic genera emphasize biogeographic importance of Asia in intercontinental dispersal events. Interestingly, four of these genera (Pentabuneomys, Leptodontomys/Eomyops, Apeomys, Megapeomys) show Holarctic distributions. Based on chronological occurrence and dental morphology, Pentabuneomys and Leptodontomys/Eomyops show a unidirectional migration, dispersing from North America into Eurasia probably by the early Miocene. Apeomyine eomyids likely had higher dispersal ability, showing at least two intercontinental dispersal events. Apeomys most likely originated in North America and then migrated into Eurasia during the late Oligocene given that two more basal apeomyine eomyids (Zophoapeomys, Proapeomys) predate Apeomys whistleri in North America (Korth 2008, Korth and Samuels 2015). Later, the apeomyine Megapeomys dispersed into North America, as suggested by the occurrence of a more basal species of Megapeomys in Japan than in North America (Tomida 2011) and the presence of more derived apeomyine taxa (Apeomyoides savagei) in North America (Korth 2008, Korth and Samuels 2015). The remaining three genera of the Asian eomyids are Eomys, Keramidomys, and Ligerimys, all of which occurred in Europe as well. In Eurasia, Eomys represents the oldest-known eomyid genus (locality Möhren 19, Germany, MP 21; locality Ronzon, France, MP 21, earliest Oligocene; Maridet et al. 2010) and is therefore associated with the first dispersal event of eomyid rodents from North America into Europe (Fahlbusch 1973, 1979, Engesser 1999). In Asia, scarce material of E. orientalis has been recovered from the early to late Oligocene of Central Mongolia and Inner Mongolia, China (Wang and Emry 1991, Maridet et al. 2015). More evidence of early dispersals of eomyid rodents is expected from these areas. Given that recent phylogenetic analysis indicates that
Keramidomys is related to the Asian endemics Asianeomys and Japaneomys (Kimura et al. 2019), Keramidomys likely originated in Asia and later dispersed westward. Asian Ligerimys is unique compared to other eomyids because its geographic range was mainly limited to western Europe before the discovery of early Miocene L. asiaticus (MN 2 MN 3) in Inner Mongolia (Qiu and Li 2016). The occurrence of Asian Ligerimys suggests that this genus opportunistically dispersed eastward from Europe, seemingly without leaving diverse local descendants.

\section{Eomyid diversity through time with emphasis on Asia}

Eomyid rodents originated in North America during the middle Eocene (Korth 1994) and then dispersed into Asia during the late Eocene (Emry et al. 1997) and into Europe by the early Oligocene (Engesser 1999). They were remarkably successful and widely distributed in the Holarctic but disappeared by the end of the Miocene in North America and by the early Pleistocene in Eurasia (Engesser 1999, Flynn 2008). Text-fig. 10 compares the occurrences of eomyid genera in the fossil record of North America, Europe and Asia (Tab. 1). After the earliest occurrence of eomyid rodents in the middle Eocene ( $43.3 \mathrm{Ma})$ of North America, eomyid rodent diversity steadily increased and achieved a high plateau by $39 \mathrm{Ma}$, lasting for $\sim 3$ million years. The increased diversity occurred during progressive global cooling in the late Eocene (Zachos et al. 2001). Taking singleton taxa into consideration, the highest peak of eomyid diversity occurred in the late Eocene ( $\sim 36 \mathrm{Ma})$ (updated in this study; see also Korth 1994, Flynn 2008). Even though eomyids dispersed from North America during the late Eocene (Asia) and earliest Oligocene (Europe), their diversity was initially low outside North America (Text-fig. 10). In North America, eomyid diversity progressively declined across the EoceneOligocene boundary, coinciding with the onset of Antarctic glaciation and the first occurrence of permanent ice-sheets (Zachos et al. 2001). This was a time of major turnover events in mammal faunas, the so-called "Grande Coupure" (= the Great Cut) in Europe and Mongolian Remodelling in Asia (see Meng and McKenna 1988, Costa et al. 2011). Eomyid diversity continuously decreased and reached a low level in the early Oligocene, but it slightly bounced back in the late early Oligocene, counting singleton taxa. However, North American eomyids hit their lowest diversity during the major expansion of the Antarctic glaciation (i.e., Oi-2b glacial event) in the late Oligocene. Only a single genus, the ubiquitous Leptodontomys, survived the cooling event. After the Oi-2a and Oi-2b glaciation events at $28 \mathrm{Ma}-26.7 \mathrm{Ma}$ (Wade and Pälike 2004), eomyid diversity in North America remained at a low level and did not recover even during the mid-Miocene Climatic Optimum (17 Ma to $15 \mathrm{Ma}$ ), whereas eomyids flourished both in Europe and Asia at that time (Textfig. 10). They were apparently diverse and successful in the warm (tropical to subtropical) dense forest environments in the late Eocene of North America, and their rapid decline during the Oligocene coincides with the expansion of open habitats including dry woodlands and grasslands (Retallack 2001, Strömberg 2011). 

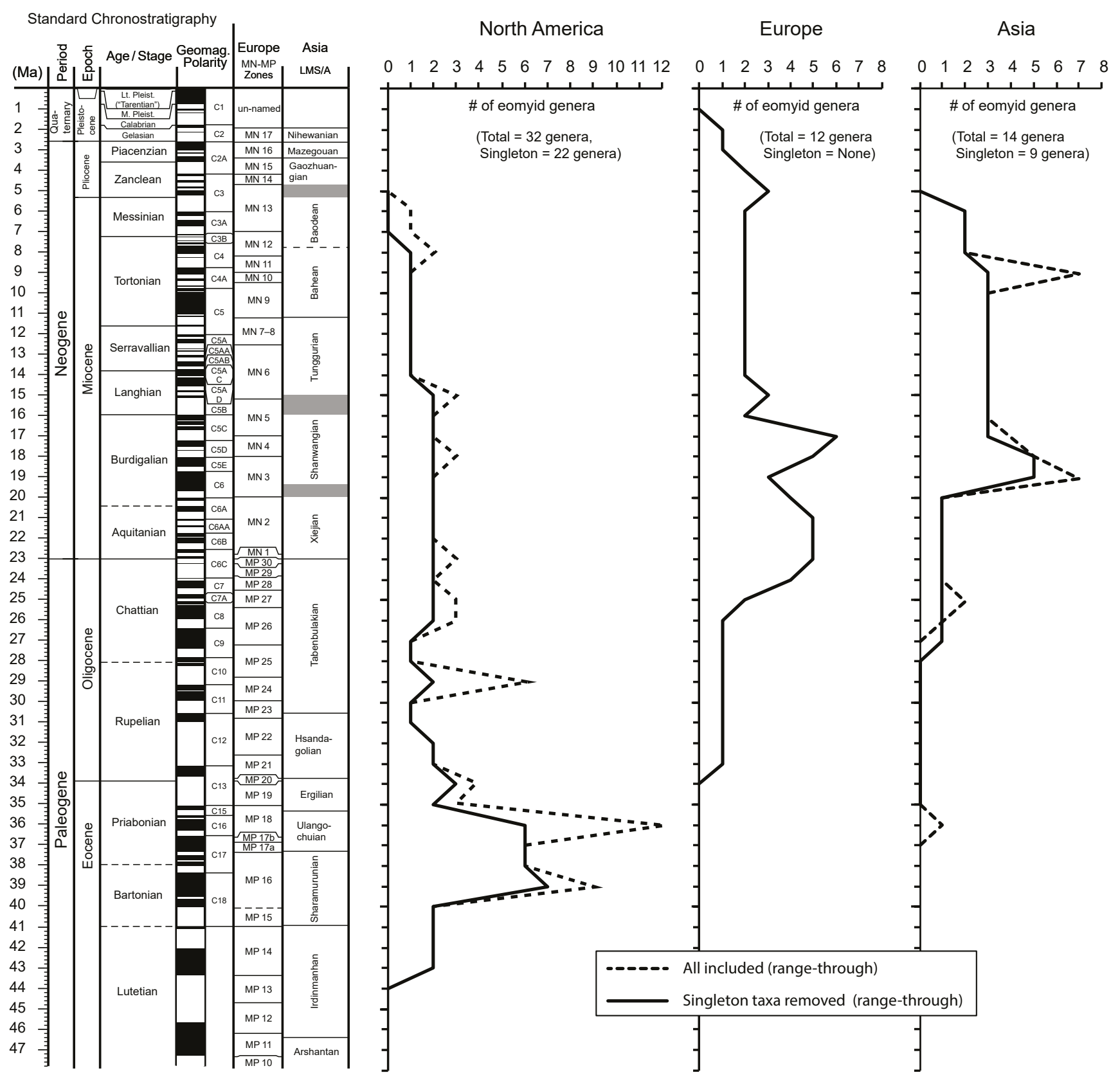

Text-fig. 10. Diversity of eomyid rodents in North America, Europe, and Asia, counted as "range-through" occurrences of eomyid genera. Two datasets were used to generate the diversity curves. All taxa were included in one dataset (solid line), and in the other dataset (dashed line), singleton taxa, were removed (any genera whose first and last occurrences are restricted to a single time bin; Sepkoski 1996). In each time bin, a data point is placed in its median age. References for standard chronostratigraphy and mammalian biostratigraphy follow Text-fig. 2.

In Eurasia, eomyid rodents diversified somewhat but were never as diverse as the late Eocene taxa of North America. They diversified sufficiently after their diversification and subsequent decline in North America. A singleton genus, Symplokeomys, from Kazakhstan is the only Eurasian representative contemporaneous with the highest eomyid diversity in North America (Text-figs 2, 10). Eomys is the earliest taxon to appear more persistently in the fossil record of Eurasia. Although the genus is more commonly known from the Oligocene of Europe (e.g., Comte and Vianey-Liaud 1987, Engesser 1990, Maridet et al. 2010), Eomys fossils, including those under provisional taxonomic assignments, have been reported from Mongolia (Daxner-Höck 2010, Maridet et al. 2015) in addition to the type locality of the only Asian species, E. orientalis, from Inner Mongolia (Wang and Emry 1991) (see Appendix). Eomyid rodents experienced their highest generic diversity during the middle to late Burdigalian stage in Eurasia. A remarkable peak is observed in Europe at $17 \mathrm{Ma}$ (Engesser 1999), which corresponds to the beginning of the mid-Miocene Climatic Optimum (Zachos et al. 2001), whereas a slight increase of generic diversity predated the warming event in Asia (Text-fig. 10). In Europe, the subsequent decline in eomyid diversity coincides with the end of the mid-Miocene Climatic Optimum (Zachos et al. 2001), but complex biotic factors may also have played an important role. Particularly, "modern" cricetid rodents like Democricetodon and Megacricetodon dispersed into Europe 
at $\sim 18 \mathrm{Ma}$ and soon became major components of rodent faunas (Daams et al. 1988, Aguilar et al. 1999). These early cricetids, showing a generalized bunolophodont dentition, are considered to have been opportunists adapted to diverse environments including more arid habitats (Gómez Cano et al. 2017); however, they may also have competed with eomyids in more forested environments.

On the other hand, Asian eomyid diversity remained rather static during most of the Miocene, especially after the middle Burdigalian diversity peak (Text-fig. 10). The genera present in this interval are the long-ranging Asianeomys, Keramidomys, and Leptodontomys, which are well-represented in the intensively surveyed sections of Inner Mongolia (e.g., Qiu and Li 2016). Ecometric studies show that central East Asia was consistently more arid than Southern Europe throughout the Neogene (Eronen et al. 2010, Fortelius et al. 2014), which could have limited eomyid diversity.

By the end of the Pliocene, eomyid rodents disappeared in North America and Asia, whereas they survived until the early Pleistocene in northern Europe. Global climatic cooling resulted in the extension of grass-dominated ecosystems in the late Miocene (Quade and Cerling 1995, Cerling et al. 1997, Tipple and Pagani 2007), whereas in Europe, warmtemperate forest environments persisted in many areas and at higher latitudes although arid landscapes existed in the Mediterranean regions since the middle Miocene (JiménezMoreno and Suc 2007, but see Quan et al. 2014). The persistent warm-temperate forest environments may explain the much later extinction of eomyids in Europe. In Asia, even after extensive field efforts, no eomyid fossils have been found in Pliocene localities in Inner Mongolia, China (Qiu and Storch 2000). It seems reasonable that the earlier regional disappearance is a true signal in Inner Mongolia due to the ongoing aridification in central Asia linked to the intensification of the monsoon climate (e.g., An et al. 2001, Liu and Yin 2002, Biasati et al. 2010). However, considering the discovery of late Miocene eomyids (Qiu 2006, Qiu 2017) from Yunnan Province (southwestern China), it is possible that eomyid refuges existed during a certain time period in southern China or continental Southeast Asia. The exploration of new regions and the intensive sampling of known fossiliferous areas may eventually test such a hypothesis.

\section{Acknowledgements}

We thank T. Goda and T. Yasuno for donating important specimens to NMNS, Japan; S. Suzuki for beautiful scientific illustrations; M. Yagishita for her volunteer work in Y.K.'s lab. We sincerely thank constructive and insightful comments by reviewers, L. L. Jacobs and L. J. Flynn, which significantly improved the quality of this manuscript. We are grateful to the editorial team of Fossil Imprint, especially to T. Lehmann and J. Wagner for handling our manuscript. Y.K. received financial support from the Japan Society for the Promotion of Science, Tokyo, Japan (JSPS, KAKENHI Grant Number JP18K13650, Grant-in-Aid for Early-Career Scientists) and also from the National Museum of Nature and Science as part of a research project called "Chemical Stratigraphy and Dating as a Clue for Understanding the History of the Earth and Life". I.C.-V. was financially supported by the Spanish Ministerio de Economía, Industria y Competitividad, the Agencia Estatal de Investigación and the European Regional Development Fund of the European Union (projects CGL2016-76431-P, AEI/ FEDER EU, CGL2017-82654-P MINECO/FEDER EU; and research contract RYC-2013-12470), and the Generalitat de Catalunya (CERCA Programme). I.C.-V. is a member of the consolidated research group 2017 SGR 116 of the Generalitat de Catalunya. O.M.'s research is supported by a grant of the Swiss National Science Foundation ( $N^{\circ}$ 200021-162359). D.C.K acknowledges the Deutsche Forschungsgemeinschaft (DFG, Bonn, Germany) for various grants to study mammalian enamel microstructure. T.M. was financially supported by The Royal Swedish Academy of Sciences (KVA, Stockholm, Sweden) and by JSPS, Tokyo, Japan.

\section{References}

Aberhan, M., Kiessling, W. (2012): Phanerozoic marine biodiversity: A fresh look at data, methods, patterns and processes. - In: Talent, J. A. (ed.), Earth and Life: Global Biodiversity, Extinction Intervals and Biogeographic Perturbations Through Time. Springer Netherlands, Dordrech, pp. 3-22. https://doi.org/10.1007/978-90-481-3428-1_1

Aguilar, J. P., Escarguel, G., Michaux, J. (1999): A succession of Miocene rodent assemblages from fissure fillings in southern France: palaeoenvironmental interpretation and comparison with Spain. - Palaeogeography, Palaeoclimatology, Palaeoecology, 145: 215-230. https://doi.org/10.1016/S0031-0182(98)00103-5

An, Z., Kutzbach, J. E., Prell, W. L., Porter, S. C. (2001): Evolution of Asian monsoons and phased uplift of the Himalaya-Tibetan plateau since Late Miocene times. Nature, 411: 62-66. https://doi.org/10.1038/35075035

Bendukidze, O. G., de Bruijn, H., van den Hoek Ostende, L. W. (2009): A revision of Late Oligocene associations of small mammals from the Aral Formation (Kazakhstan) in the National Museum of Georgia, Tbilissi. - Palaeodiversity, 2: 343-377.

Bi, S.-D., Meng, J., McLean, S., Wu, W.-Y., Ni, X.-J., Ye, J. (2013): A new genus of aplodontid rodent (Mammalia, Rodentia) from the Late Oligocene of northern Junggar Basin, China. - PLoS ONE, 8(1): e52625 (8 pp.). https://doi.org/10.1371/journal.pone.0052625

Biasatti, D., Wang, Y., Deng, T. (2010): Strengthening of the East Asian summer monsoon revealed by a shift in seasonal patterns in diet and climate after 2-3 Ma in northwest China. - Palaeogeography, Palaeoclimatology, Palaeoecology, 297: 12-25. https://doi.org/10.1016/j.palaeo.2010.07.005

de Bruijn, H., Doukas, C. D., van den Hoek Ostende, L.W., Zachariasse, W. J. (2012): New finds of rodents and insectivores from the Upper Miocene at Plakias (Crete, Greece). - Swiss Journal of Palaeontology, 131: 61-75. https://doi.org/10.1007/s13358-011-0030-7

Cerling, T. E., Harris, J. M., MacFadden, B. J., Leakey, M. G., Quade, J., Eisenmann, V., Ehleringer, J. R. (1997): 
Global vegetation change through the Miocene/Pliocene boundary. - Nature, 389: 153-158.

https://doi.org/10.1038/38229

Comte, B., Vianey-Liaud, M. (1987): New Eomyidae Paleogene localities in Western Europe. - Comptes rendus de l'Académie des sciences, Série 2, 304: 951-955.

Cope, E. D. (1884): The Vertebrata of the Tertiary formations of the West. - Report of the United States Geological Survey of the Territories, 3: ix-xxxiv +2 unpaginated pp. (Errata) + 1-1009.

Costa, E., Garcés, M., Sáez, A., Cabrera, L., López-Blanco, M. (2011): The age of the "Grande Coupure" mammal turnover: New constraints from the Eocene-Oligocene record of the Eastern Ebro Basin (NE Spain). - Palaeogeography, Palaeoclimatology, Palaeoecology, 301: 97-107. https://doi.org/10.1016/j.palaeo.2011.01.005

Daams, R., Freudenthal, M., van der Meulen, A. J. (1988): Ecostratigraphy of micromammal faunas from the Neogene of the Calatayud-Teruel Basin. - Scripta Geologica, Special issue 1: 287-302.

Daxner-Höck, G. (2010): Sciuridae, Gliridae and Eomyidae (Rodentia, Mammalia) from the Middle Miocene of St. Stefan in the Gratkorn Basin (Styria, Austria). - Annalen des Naturhistorischen Museum in Wein, Serie A, 112: 507-536.

Daxner-Höck, G., Badamgarav, D., Barsbold, R., Bayarmaa, B., Erbajeva, M., Göhlich, U. B., Harzhauser, M., Höck, E., Höck, V., Ichinnorov, N., Khand, Y., López-Guerrero, P., Maridet, O., Neubauer, T., Oliver, A., Piller, W., Tsogtbaatar, K., Ziegler, R. (2017): Oligocene stratigraphy across the Eocene and Miocene boundaries in the Valley of Lakes (Mongolia). - In: Daxner-Höck, G., Göhlich, U. (eds), The Valley of Lakes in Mongolia, a key area of Cenozoic mammal evolution and stratigraphy. Palaeobiodiversity and Palaeoenvironments, 97: 111-218. https://doi.org/10.1007/s12549-016-0257-9

Daxner-Höck, G., Böhme, M., Kossler, A. (2013): Chapter 22. New data on Miocene biostratigraphy and paleoclimatology of Olkhon Island (Lake Baikal, Siberia). - In: Wang, X., Flynn, L., Fortelius, M. (eds), Fossil Mammals of Asia: Neogene Biostratigraphy and Chronology. Columbia University Press, New York, pp. 508-519. https://doi.org/10.7312/wang15012-022

Deng, T. (2006): Chinese Neogene mammal biochronology. - Vertebrata PalAsiatica, 44: 143-163. https://doi.org/10.1080/02724634.1997.10010966

Emry, R. J., Wang, B.-Y., Tjutkova, L. A., Lucas, S. G. (1997): A late Eocene eomyid rodent from the Zaysan Basin of Kazakhstan. - Journal of Vertebrate Paleontology, 17: 229-234.

Engesser, B. (1979): Relationships of some insectivores and rodents from the Miocene of North America and Europe. - Bulletin of Carnegie Museum of Natural History, 14: $1-68$.

Engesser, B. (1990): Die Eomyidae (Rodentia, Mammalia) der Molasse der Schweiz und Savoyens. - Schweizerische Paläontologische Abhandlungen, 112: 1-144.

Engesser, B. (1999): Family Eomyidae. - In: Rössner, G. E., Heissig, K. (eds), The Miocene Land Mammals of Europe. Verlag Dr Friedrich Pfeil, München, pp. 319-335.
Engler, T., Martin, T. (2015): A partial skeleton of the eomyid Eomyodon volkeri Engesser, 1987 (Mammalia: Rodentia) from the late Oligocene Fossil-Lagerstätte of Enspel, Germany. - Palaeobiodiversity and Palaeoenvironments, 95: 133-147. https://doi.org/10.1007/s12549-014-0174-8

Eronen, J. T., Puolamäki, K., Liu, L., Lintulaakso, K., Damuth, J., Janis, C., Fortelius, M. (2010): Precipitation and large herbivorous mammals II: application to fossil data. - Evolutionary Ecology Research, 12: 235-248.

Escarguel, G., Aguilar, J.-P. (1997): Les éomyidés Pseudotheridomys et Ligerimys (Rodentia, Mammalia) du Miocène inférieur du Sud de la France. Evolution et biostratigraphie. - Palaeontographica, Abt. A, 247: 25-58.

Fahlbusch, V. V. (1968): Neue Eomyidae (Rodentia, Mamm.) aus einer aquitanen spaltenfüllung von Weißenburg in Bayern. - Mitteilungen der Bayerischen Staatssammlung für Paläontologie und historische Geologie, 8: 219-245.

Fahlbusch, V. V. (1973): Die stammesgeschichtlichen Beziehungen zwischen den Eomyiden (Mammalia, Rodentia) Nordamerikas und Europas. - Mitteilungen der Österreichischen Geologischen Gesellschaft, 13: 141-175.

Fahlbusch, V. V. (1979): Eomyidae - Geschichte einer Säugetierfamilie. - Paläontologische Zeitschrift, 53: 88-97. https://doi.org/10.1007/BF02987790

Fejfar, O., Rummel, M., Tomida, Y. (1998): New eomyid genus and species from the Early Miocene (MN Zones 3-4) of Europe and Japan related to Apeomys (Eomyidae, Rodentia, Mammalia). - National Museum of Nature and Science Monographs, 14: 123-143.

Flynn, L. J. (2008): Eomyidae. - In: Janis, C. M., Gunnell, G. F., Uhen, M. D. (eds), Evolution of Tertiary Mammals of North America: Volume 2, Small Mammals, Xenarthrans, and Marine Mammals. Cambridge University Press, New York, pp. 415-427.

https://doi.org/10.1017/CBO9780511541438.026

Flynn, L. J., Qi, G.-Q. (1982): Age of the Lufeng, China, hominoid locality. - Nature, 298: 746-747. https://doi.org/10.1038/298746a0

Fortelius, M., Eronen, J. T., Kaya, F., Tang, H., Raia, P., Puolamäki, K. (2014): Evolution of Neogene mammals in Eurasia: Environmental forcing and biotic interactions. - Annual Review of Earth and Planetary Sciences, 42: 579-604. https://doi.org/10.1146/annurev-earth-050212-124030

Gómez Cano, A. R., Kimura, Y., Blanco, F., Menéndez, I., Álvarez-Sierra, M. A., Hernández Fernández, M. (2017): Ecomorphological characterization of murines and non-arvicoline cricetids (Rodentia) from South-Western Europe since the latest Middle Miocene to the Mio-Pliocene Boundary (MN 7/8-MN13). - PeerJ, 5: e3646 (27 pp.). https://doi.org/10.7717/peerj.3646

Gomes Rodrigues, H., Marivaux, L., Vianey-Liaud, M. (2014): Rodent paleocommunities from the Oligocene of Ulantatal (Inner Mongolia, China). - Palaeovertebrata, 38(1): e3 (11 pp.).

https://doi.org/10.18563/pv.38.1.e3

Hartenberger, J.-L. (1966): Les rongeurs du Vallésien (Miocène supérieur) de Can Llobateres (Sabadell, Es- 
pagne). - Bulletin de la Société géologique de France, $7^{\mathrm{e}}$ série, 8(4): 596-604.

https://doi.org/10.2113/gssgfbull.S7-VIII.4.596

Hilgen, F. J., Lourens, L. J., van Dam, J. A. (2012): The Neogene Period. - In: Gradstein, F. M., Ogg, J. G., Schmitz, M. D., Ogg, G. (eds), The Geological Time Scale 2012. Elsevier Science Ltd, Oxford, pp. 923-978. https://doi.org/10.1016/B978-0-444-59425-9.00029-9

Hugueney, M., Mein, P. (1968): Les Eomyidés (Mammalia, Rodentia) néogènes de la région lyonnaise. - Géobios, 1: 187-204. https://doi.org/10.1016/S0016-6995(68)80007-5

Jiménez-Moreno, G., Suc, J.-P. (2007): Middle Miocene latitudinal climatic gradient in Western Europe: Evidence from pollen records. - Palaeogeography, Palaeoclimatology, Palaeoecology, 253: 208-225.

https://doi.org/10.1016/j.palaeo.2007.03.040

Kimura, Y., Tomida, Y., Kalthoff, D. C., Casanovas-Vilar, I., Mörs, T. (2019): A new endemic genus of eomyid rodents from the early Miocene of Japan. - Acta Palaeontologica Polonica, 64: 303-312.

https://doi.org/10.4202/app.00558.2018

Korth, W. W. (1992): Fossil small mammals from the Harrison Formation (late Arikareean: earliest Miocene), Cherry County, Nebraska. - Annals of Carnegie Museum, 61: 69-131.

Korth, W. W. (1994): The Tertiary Record of Rodents in North America. - Plenum Press, New York, London, 320 pp. https://doi.org/10.1007/978-1-4899-1444-6

Korth, W. W. (2008): Early Arikareean (late Oligocene) Eomyidae (Mammalia, Rodentia) from Nebraska. Paludicola, 6: 144-154.

Korth, W. W., Samuels, J. X. (2015): New rodent material from the John Day Formation (Arikareean, middle Oligocene to early Miocene) of Oregon. - Annals of the Carnegie Museum, 83: 19-84.

https://doi.org/10.2992/007.083.0102

Lindsay, E. H. (1972): Small mammal fossils from the Barstow Formation, California. - University of California publications in geological sciences, 93: 1-104.

Liu, X., Yin, Z. (2002): Sensitivity of East Asian monsoon climate to the uplift of the Tibetan Plateau. - Palaeogeography, Palaeoclimatology, Palaeoecology, 183: 223-245. https://doi.org/10.1016/S0031-0182(01)00488-6

Lopatin, A. V. (2000): New Early Miocene Aplodontidae and Eomyidae (Rodentia, Mammalia) from the Aral Formation of the Altynshokysu. - Paleontological Journal, 34: 198-202.

Maridet, O., Costeur, L., Legendre, S. (2013): European Neogene rodent communities: explaining family-level replacements through a spatiotemporal approach. - Historical Biology, 25: 655-677. https://doi.org/10.1080/08912963.2012.739170

Maridet, O., Daxner-Höck, G., Badamgarav, D., Göhlich, U. B. (2015): The eomyid rodents (Mammalia) from the Oligocene and Miocene of the Valley of Lakes (Central Mongolia). - Paläontologische Zeitschrift, 89(2): 207-228. https://doi.org/10.1007/s12542-014-0224-6

Maridet, O., Hugueney, M., Heissig, K. (2010): New data about the diversity of Early Oligocene eomyids (Mammalia,
Rodentia) in Western Europe. - Geodiversitas, 32: 221-54. https://doi.org/10.5252/g2010n2a3

Maridet, O., Wu, W.-Y., Ye, J., Ni, X.-J., Meng, J. (2011): New discoveries of glirids and eomyids (Mammalia, Rodentia) in the Early Miocene of the Junggar basin (Northern Xinjiang province, China). - Swiss Journal of Palaeontology, 130: 315-323.

https://doi.org/10.1007/s13358-011-0022-7

Martin, L. D. (1974): New rodents from the lower Miocene Gering Formation of western Nebraska. - Occasional Papers of the Museum of Natural History of the University of Kansas, 32: 1-12.

Mein, P. (2009): The Miocene Keramidomys (Rodentia, Eomyidae) from the Sandelzhausen locality (Germany). - Paläontologische Zeitschrift, 83: 141-150. https://doi.org/10.1007/s12542-009-0003-y

Meng, J., McKenna, M. C. (1998): Faunal turnovers of Palaeogene mammals from the Mongolian Plateau. Nature, 394: 364-367. https://doi.org/10.1038/28603

Meng, J., Ye, J., Wu, W.-Y., Yue, L.-P. Ni, X.-J. (2006): A recommended boundary stratotype section for Xiejian Stage from northern Junggar Basin: implications to related bio-chronostratigraphy and environmental changes. - Vertebrata PalAsiatica, 44: 205-236.

Mörs, T., Tomida, Y., Kalthoff, D. C. (2016): A new large beaver (Mammalia, Castoridae) from the early Miocene of Japan. - Journal of Vertebrate Paleontology, 36: e1080720 (13 pp.). https://doi.org/10.1080/02724634.2016.1080720

Mörs, T., Flink, T. (2018): Large apeomyine rodents (Mammalia, Eomyidae) from the Early Miocene of Echzell, Germany. - Historical Biology, 30: 1102-1111. https://doi.org/10.1080/08912963.2017.1338695

Ni, X.-J., Qiu, Z.-D. (2002): The micromammalian fauna from the Leilao, Yuanmou hominoid locality. - Journal of Human Evolution, 42: 535-546. https://doi.org/10.1006/jhev.2001.0540

Prieto, J. (2012): The genus Eomyops EnGESSER, 1979 (Rodentia, Eomyidae) from the youngest deposits of the German part of the North Alpine Foreland Basin. - Swiss Journal of Palaeontology, 131: 95-106. https://doi.org/10.1007/s13358-011-0033-4

Qiu, Z.-D. (1994): Eomyidae in China. - In: Tomida, Y., Li, C. K., Setoguchi, T. (eds), Rodent and Lagomorph Families of Asian Origins and Diversification. National Science Museum Monographs, 8: 49-55.

Qiu, Z.-D. (2006): Eomyids (Mammalia: Rodentia) from the Late Miocene Lufeng and Yuanmou hominoid Localities, Yunnan. - Vertebrata PalAsiatica: 307-319.

Qiu, Z.-D. (2017): Several rarely recorded rodents from the Neogene of China. - Vertebrata PalAsiatica, 55: 92-109.

Qiu, Z.-D., Li, Q. (2016): Neogene rodents from central Nei Mongol, China. - Palaeontologia Sinica, New Serie, C, 198 (N. S. 30): 1-676.

Qiu, Z.-D., Storch, G. (2000): The early Pliocene micromammalian fauna of Bilike, Inner Mongolia, China (Mammalia: Lipotyphla, Chiroptera, Rodentia, Lagomorpha). - Senckenbergiana lethaea, 80: 173-229. https://doi.org/10.1007/BF03043669 
Qiu, Z.-D., Wang, X.-M., Li, Q. (2013): Neogene faunal succession and biochronology of central Nei Mongol (Inner Mongolia). - In: Fossil Mammals of Asia: Neogene Biostratigraphy and Chronology. Columbia University Press, New York, pp. 155-186. https://doi.org/10.7312/columbia/9780231150125.003.0005

Qiu, Z.-X., Qiu, Z.-D., Deng, T., Li, C.-K., Zhang, Z.-Q., Wang, B.-Y., Wang, X.-M. (2013): Neogene land mammal stages/ages of China. - In: Wang, X., Lawrence, J. F., Fortelius, M. (eds), Fossil Mammals of Asia: Neogene Biostratigraphy and Chronology. Columbia University Press, New York, pp. 29-90. https://doi.org/10.7312/columbia/9780231150125. 003.0001

Quade, J., Cerling, T. E. (1995): Expansion of $C_{4}$ grasses in the Late Miocene of northern Pakistan: Evidence from stable isotopes in paleosols. - Palaeogeography, Palaeoclimatology, Palaeoecology, 115: 91-116. https://doi.org/10.1016/0031-0182(94)00108-K

Quan, C., Liu, Y.-S. C., Tang, H., Utescher, T. (2014): Miocene shift of European atmospheric circulation from trade wind to westerlies. - Scientific Reports, 4: 1-6. https://doi.org/10.1038/srep05660

Retallack, G. J. (2001): Cenozoic expansion of grasslands and climatic cooling. - Journal of Geology, 109: 407-426. https://doi.org/10.1086/320791

Ruiz-Sánchez, F. J., Calatayud, B. L., Freudenthalm, M. (2009): Eomyops noeliae sp. nov., a new Eomyidae (Mammalia, Rodentia) from the Aragonian of Spain. Comptes Rendus Palevol, 8: 375-84.

https://doi.org/10.1016/j.crpv.2008.12.002

Schlosser, M. (1884): Die Nager des europäischen Tertiärs nebst Betrachtungen über die Organisation und die geschichtliche Entwicklung der Nager überhaupt. - Palaeontographica, 31: 19-162.

Sepkoski, J. J. Jr. (1996): Patterns of Phanerozoic extinction: a perspective from global data bases. - In: Walliser, O. H. (ed.), Global Events and Event Stratigraphy in the Phanerozoic. Springer, Berlin, pp. 35-51. https://doi.org/10.1007/978-3-642-79634-0_4

Shotwell, J. A. (1956): Hemphillian mammalian assemblages from northeastern Oregon. - Bulletin of the Geological Society of America, 67: 717-736. https://doi.org/10.1130/0016-7606(1956)67[717:HMAF$\mathrm{NO}] 2.0 . \mathrm{CO} ; 2$

Smith, K. S., Cifelli, R. L., Czaplewski, N. J. (2006): A new genus of eomyid rodent from the Miocene of Nevada. Acta Palaeontologica Polonica, 51: 385-392.

Stehlin, H., Schaub, S. (1951): Die Trigonodontie der simplicidentaten Nager. - Schweizerische palaeontologische Abhandlungen, 67: 1-385. https://doi.org/10.1515/mamm-1951-0411

Storch, G., Engesser, B., Wuttke, M. (1996): Oldest fossil record of gliding in rodents. - Nature, 379: 439-441. https://doi.org/10.1038/379439a0

Strömberg, C. A. E. (2011): Evolution of grasses and grassland ecosystems. - Annual Review of Earth and Planetary Sciences, 39: 517-544.

https://doi.org/10.1146/annurev-earth-040809-152402

Takeuchi, T. (1992): [Paleomagnetism of the Miocene Mi- zunami Group in Kani Basin, Gifu Prefecture, Japan]. Bulletin of the Mizunami Fossil Museum, 19: 57-65. [in Japanese with English abstract]

Tipple, B. J., Pagani, M. (2007): The early origins of terrestrial $\mathrm{C}_{4}$ photosynthesis. - Annual Review of Earth and Planetary Sciences, 35: 435-461.

https://doi.org/10.1146/annurev.earth.35.031306.140150

Tomida, Y. (2011): A new species of the genus Megapeomys (Mammalia, Rodentia, Eomyidae) from the Early Miocene of Japan. - Palaeontologia Electronica, 14(3): 25A (6 pp.).

Tomida, Y., Setoguchi, T. (1994): Tertiary rodents from Japan. - In: Tomida, Y., Li, C. K., Setoguchi, T. (eds), Rodent and Lagomorph Families of Asian Origins and Diversification. National Science Museum Monographs, 8: 185-195.

Vandenberghe, N., Hilgen, F. J., Speijer, R. P. (2012): The Paleogene Period. - In: Gradstein, F. M., Ogg, J. G., Schmitz, M. D., Ogg, G. (eds), The Geologic Time Scale 2012. Elsevier Science Ltd, Oxford, pp. 855-921. https://doi.org/10.1016/B978-0-444-59425-9.00028-7

Wade, B. S., Pälike, H. (2004): Oligocene climate dynamics. - Paleoceanography, 19: 1-16. https://doi.org/10.1029/2004PA001042

Wahlert, J. H. (1978): Cranial foramina and relationships of the Eomyoidea (Rodentia, Geomorpha): skull and upper teeth of Kansasimys. - American Museum Novitates, 2645: 1-16.

Wang, B.-Y. (2002): Discovery of Late Oligocene Eomyodon (Rodentia, Mammalia) from the Danghe Area, Gansu, China. - Vertebrata PalAsiatica, 40: 139-145.

Wang, B.-Y., Emry, R. J. (1991): Eomyidae (Rodentia: Mammalia) from the Oligocene of Nei Mongol, China. Journal of Vertebrate Paleontology, 11: 370-377. https://doi.org/10.1080/02724634.1991.10011404

Wang, X.-M., Wang, B.-Y., Qiu, Z.-X. (2008): Early explorations of Tabenbuluk region (western Gansu Province) by Birger Bohlin-Reconciling classic vertebrate fossil localities with modern stratigraphy. - Vertebrata PalAsiatica, 46: 1-19.

Winge, H. (1887): Jordfundne og nulevende Gnavere (Rodentia) fra Lagoa Santa, Minas Geraes, Brasilien: med Udsigt over Gnavernes indbyrdes Slaegtskab [Fossil and living rodents (Rodentia) from Lagoa Santa, Minas Geraes, Brazil: with the rodent relationship]. - Bianco Lunos Kgl. Hof-Bogtrykkeri (F. Dreyer), Kjobenhaven [= Copenhagen], 178 pp. +7 pls. (in Danish) https://doi.org/10.5962/bhl.title.14696

Wu, W.-Y., Meng, J., Ye, J., Ni, X.-J. (2006): The first finds of eomyids (Rodentia) from the Late Oligocene-Early Miocene of the Northern Junggar Basin, China. Beiträge zur Paläontologie, 30: 469-479.

Zachos, J., Pagani, M., Thomas, E., Billups, K. (2001): Trends, rhythms, and aberrations in global climate $65 \mathrm{Ma}$ to Present. - Science, 292: 686-693. https://doi.org/10.1126/science.1059412

Zheng, S.-H., Li, Y. (1982): Some Pliocene lagomorphs and rodents from Loc.1 of Songshan, Tianzu Xian, Gansu Province. - Vertebrata PalAsiatica, 20: 35-44. 


\begin{tabular}{|c|c|c|c|c|c|c|c|c|c|c|c|c|c|c|c|c|c|}
\hline 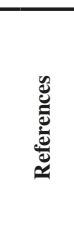 & E్ & 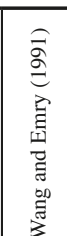 & 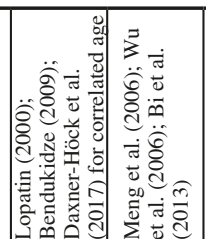 & 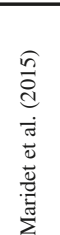 & 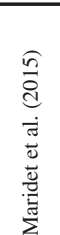 & 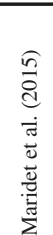 & 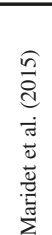 & 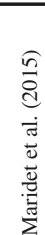 & 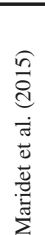 & 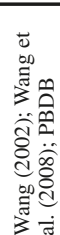 & 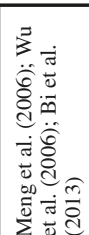 & 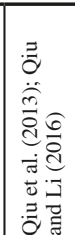 & 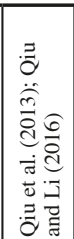 & 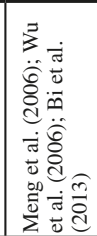 & 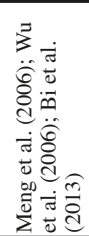 & 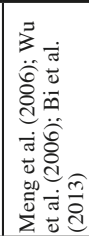 & 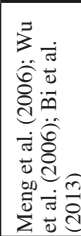 \\
\hline
\end{tabular}

\begin{tabular}{|c|c|c|c|c|c|c|c|c|c|c|c|c|c|c|c|c|c|c|c|}
\hline 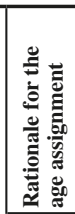 & 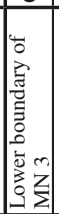 & 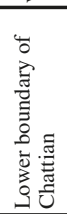 & 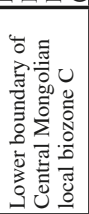 & 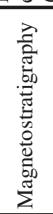 & 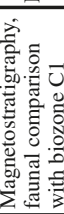 & & & & & & & 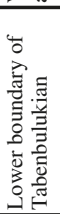 & 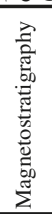 & 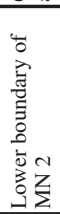 & 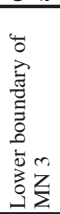 & 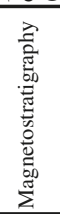 & 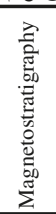 & 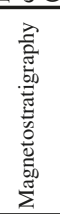 & 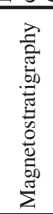 \\
\hline$\frac{1}{2}$ & $\stackrel{2}{2}$ & $\begin{array}{l}\infty \\
\stackrel{\infty}{\sim}\end{array}$ & $\frac{d}{4}$ & $\overrightarrow{\bar{v}}$ & :ें & ن. & $\begin{array}{l}0 \\
\dot{y}\end{array}$ & 이 & & & & 盛 & $\overrightarrow{\bar{\lambda}}$ & $\stackrel{\vec{\lambda}}{\vec{\lambda}}$ & $\stackrel{9}{9}$ & $\overrightarrow{\mathrm{i}}$ & $\stackrel{d}{+}$ & 热 & $\stackrel{+}{d+}$ \\
\hline & & & 0 & & & & & & & & & & & & & & & & \\
\hline
\end{tabular}

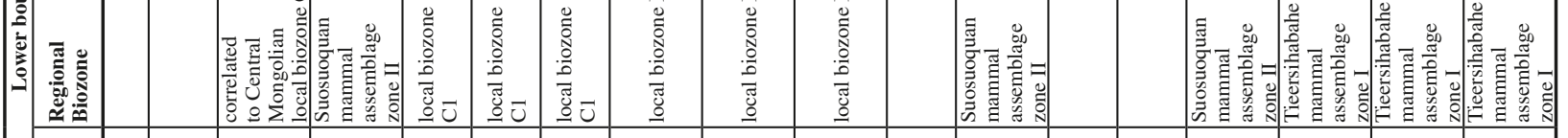

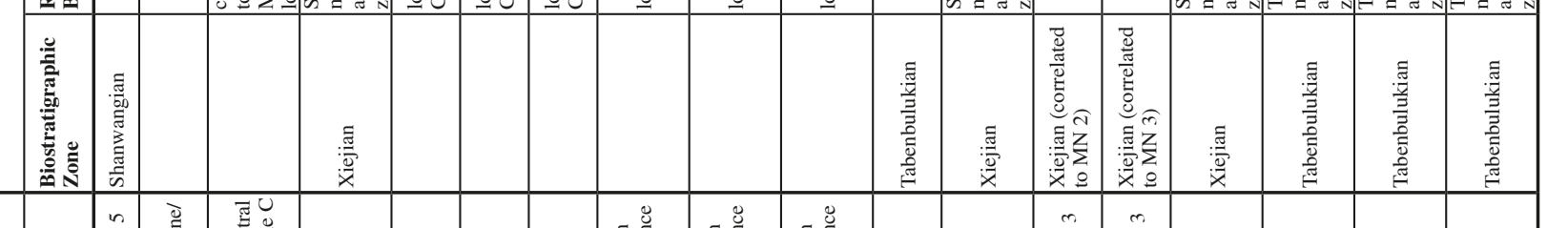

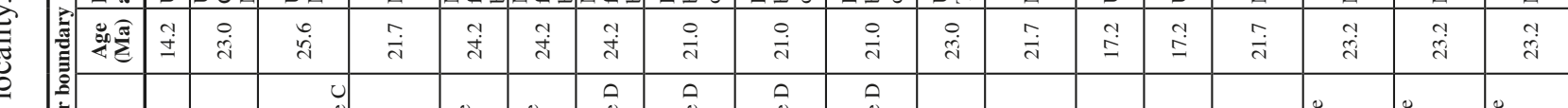

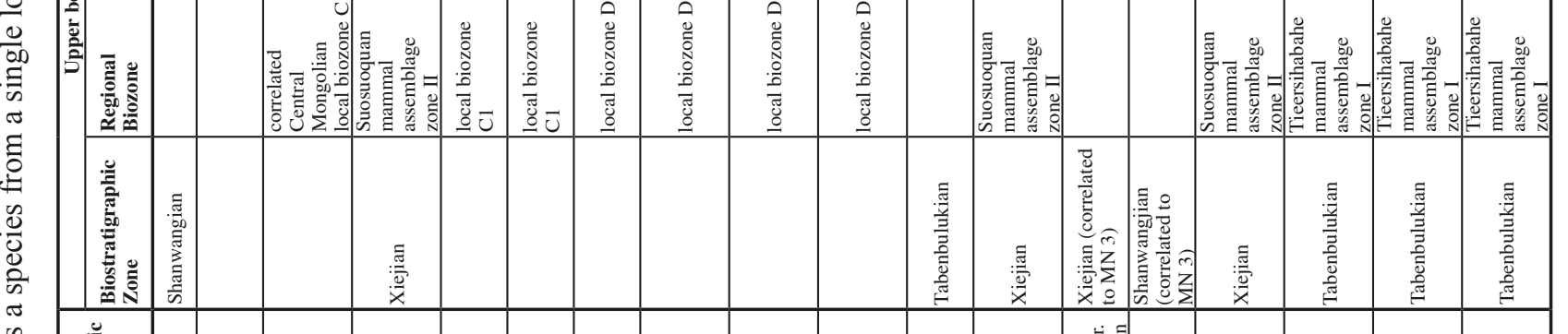

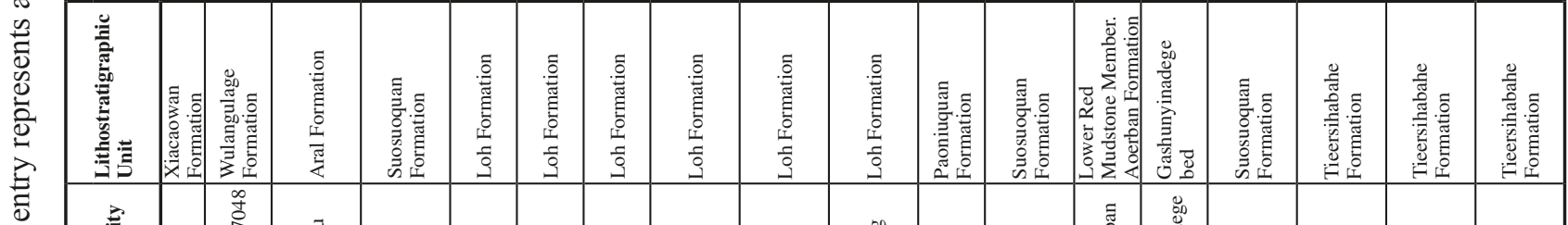

\begin{tabular}{|c|c|c|c|c|c|c|c|c|c|c|c|c|c|c|c|c|c|c|}
\hline 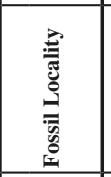 & 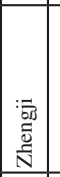 & 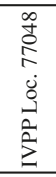 & 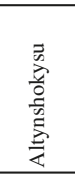 & 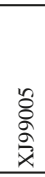 & $\stackrel{\Xi}{\beth}$ & 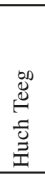 & 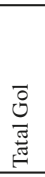 & 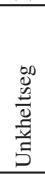 & 鸽 & 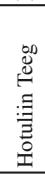 & 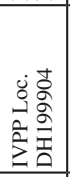 & 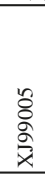 & 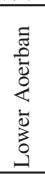 & 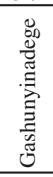 & $\begin{array}{l}\text { oे } \\
\vdots \\
\ddot{x}\end{array}$ & 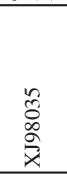 & 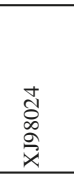 & 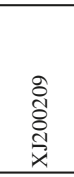 \\
\hline 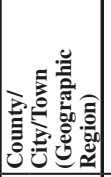 & 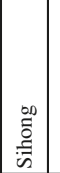 & 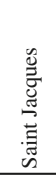 & 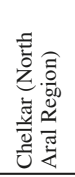 & 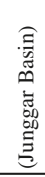 & 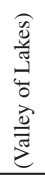 & 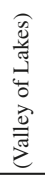 & 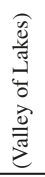 & 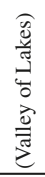 & 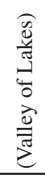 & 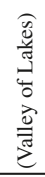 & 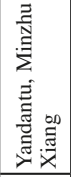 & 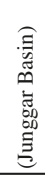 & 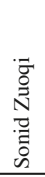 & 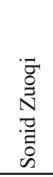 & 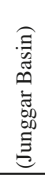 & 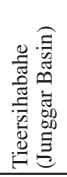 & 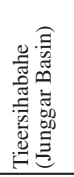 & 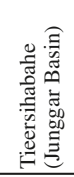 \\
\hline
\end{tabular}

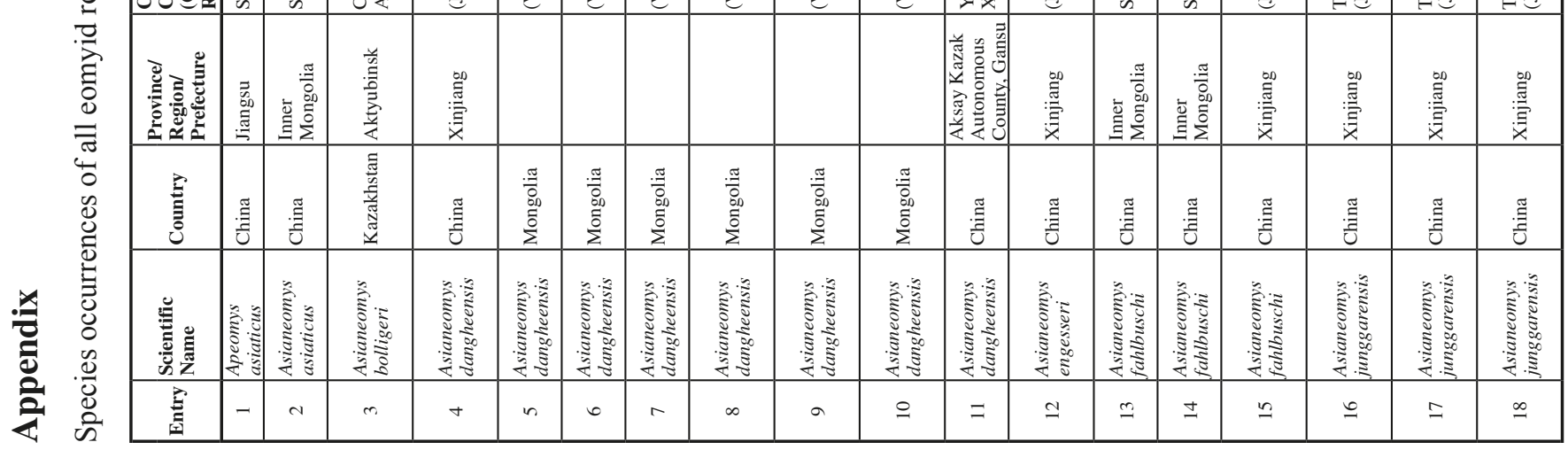




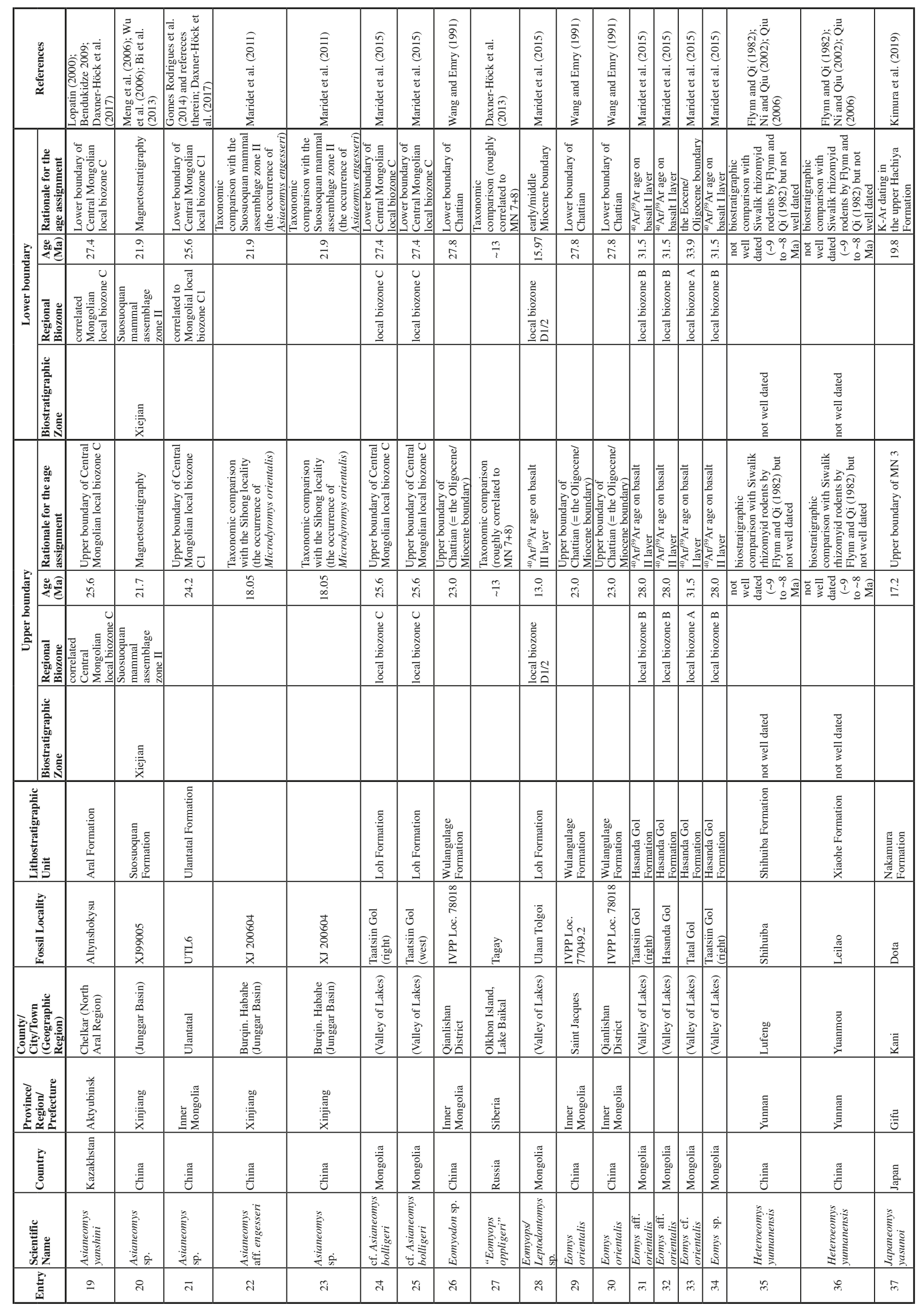




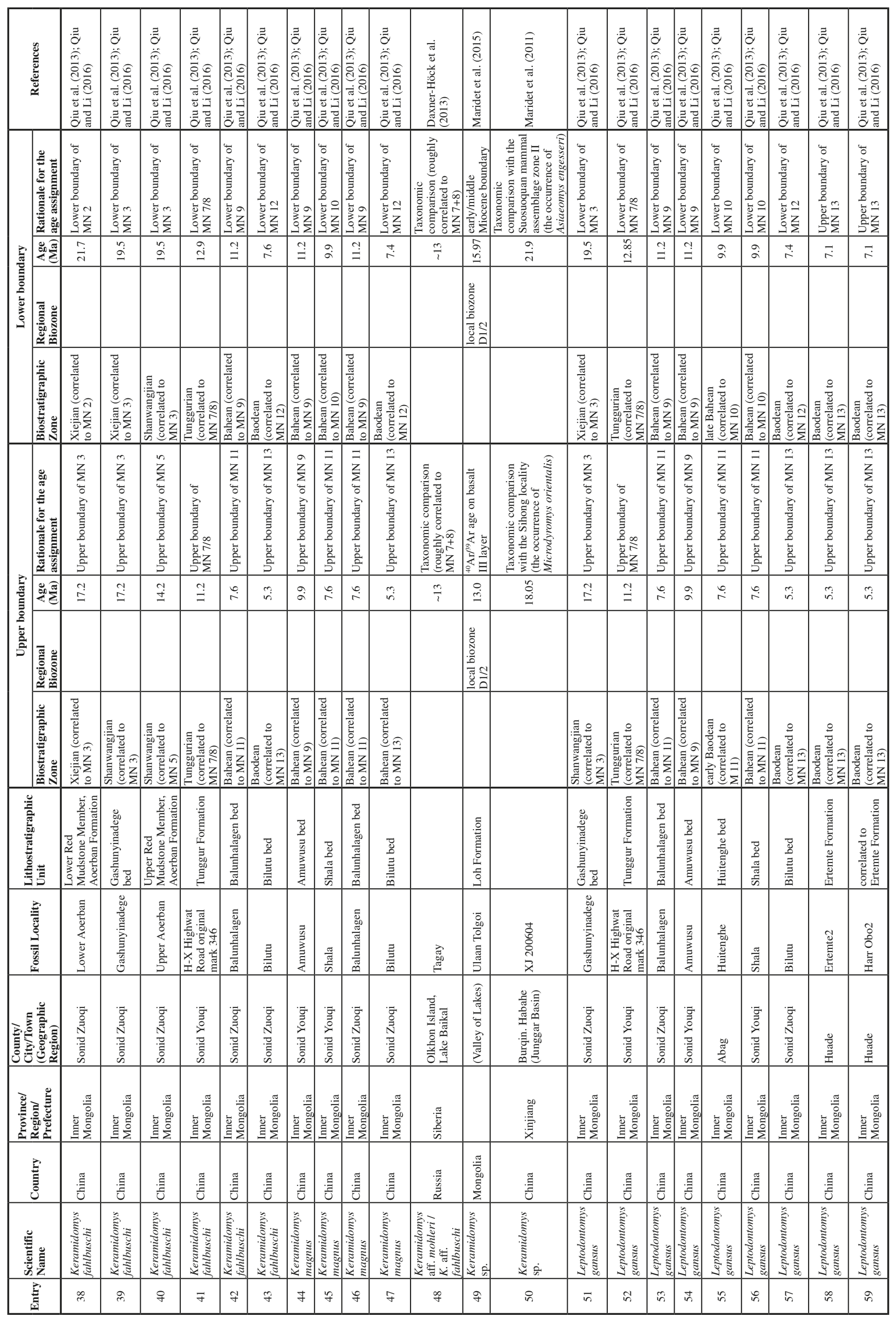




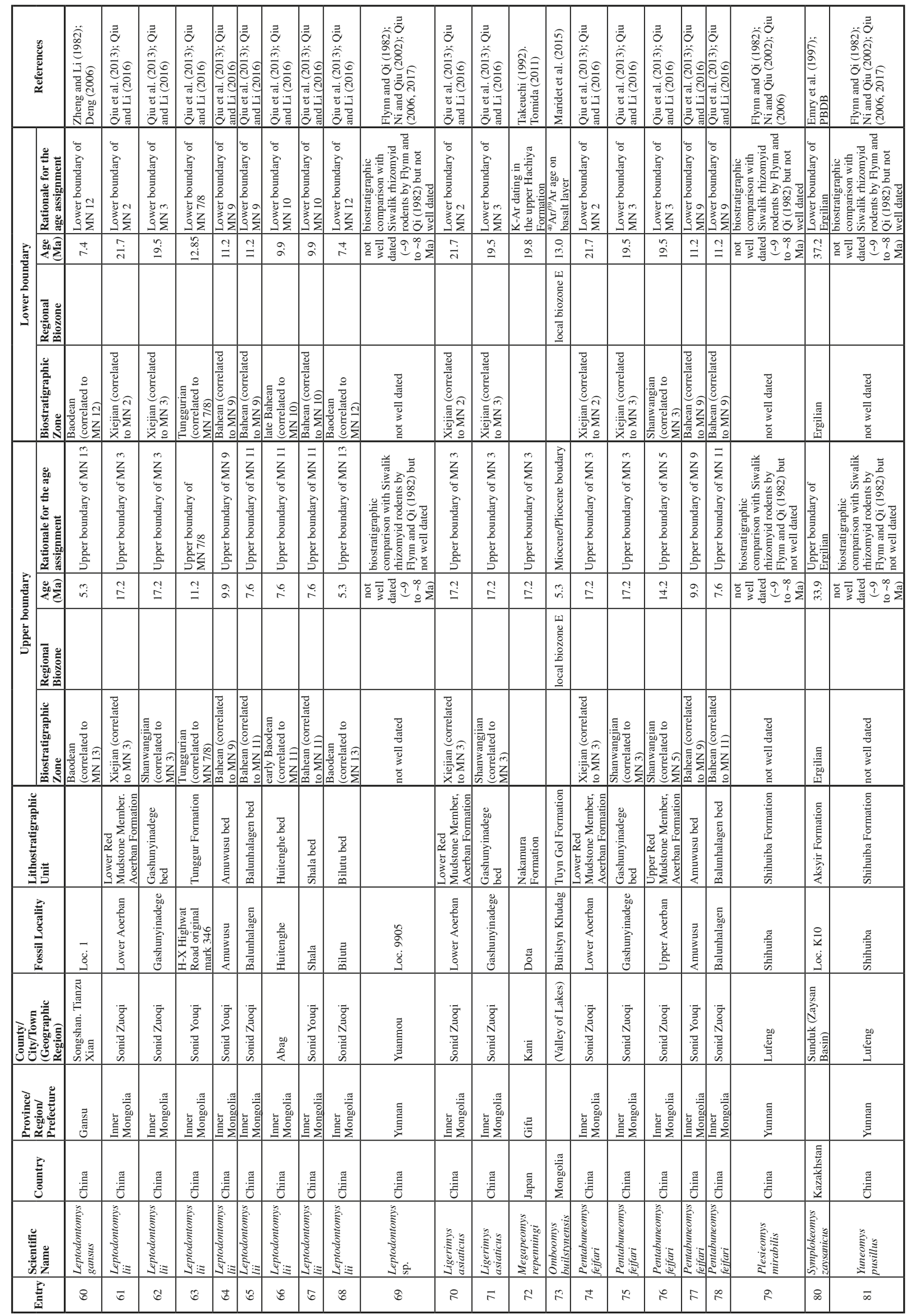

